\title{
Crescimento da Nanoapatita na Liga Ti-30Ta para Aplicações Odontológicas
}

Dissertação apresentada à Faculdade de Engenharia do Campus de Guaratinguetá, Universidade Estadual Paulista, para a obtenção do título de Mestre em Engenharia Mecânica na área de Materiais.

Orientadora: Profa. Dra.Ana Paula Rosifini Alves Claro

Co-orientadora: Profa.Dra.Maria Cristina

Rosifini Alves Rezende 


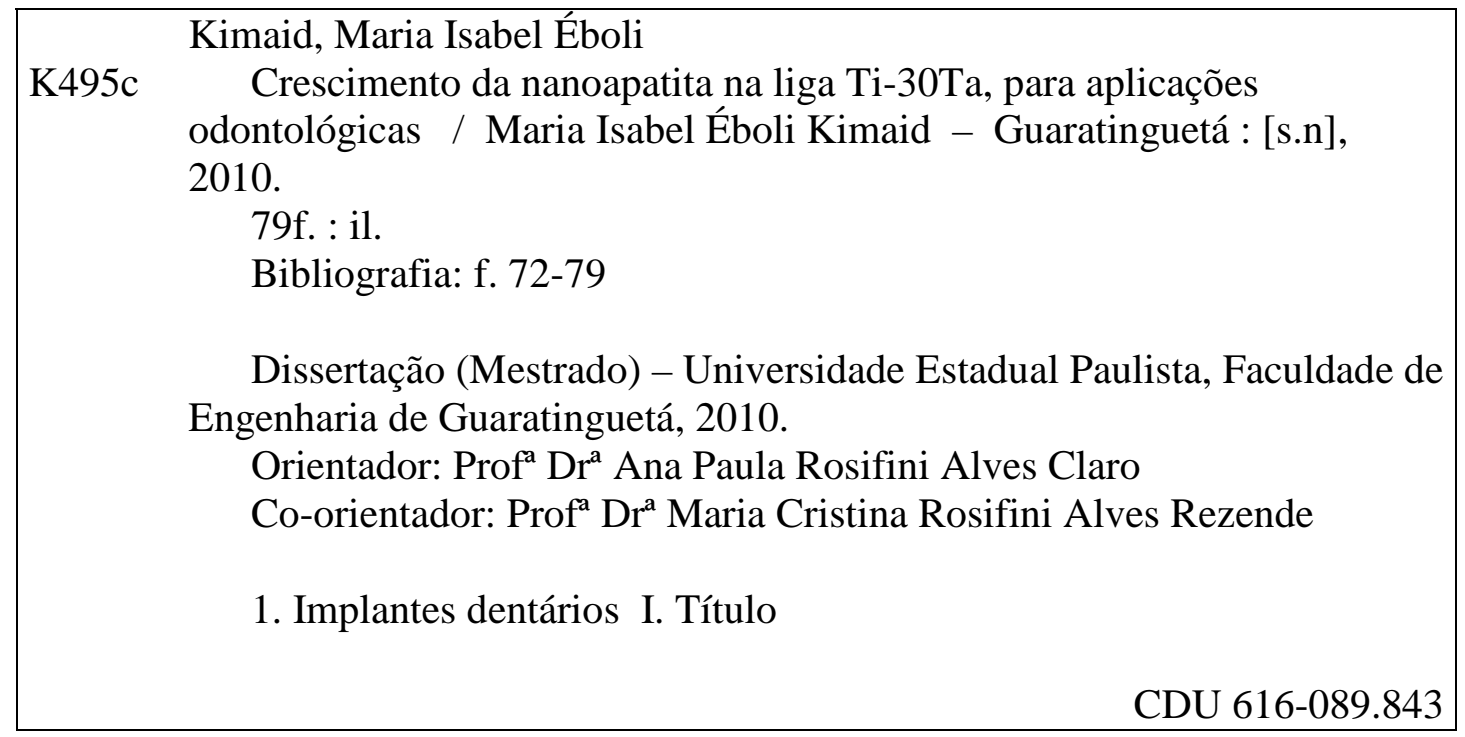


MARIA ISABEL ÉBOLI KIMAID

ESTA DISSERTAÇÃo FOI JULGADA ADEQUADA PARA A OBTENÇĀO DO TÍTULO DE "MESTRE EM CIÊNCIAS"

\section{PROGRAMA: ENGENHARIA MECÂNICA}

ÁREA: MATERIAIS

APROVADA EM SUA FORMA FINAL PELO PROGRAMA DE PÓS-GRADUAÇĀO

Prof. Dr. Marcelo dos Santos Pereira

BANCA EXAMINADORA:

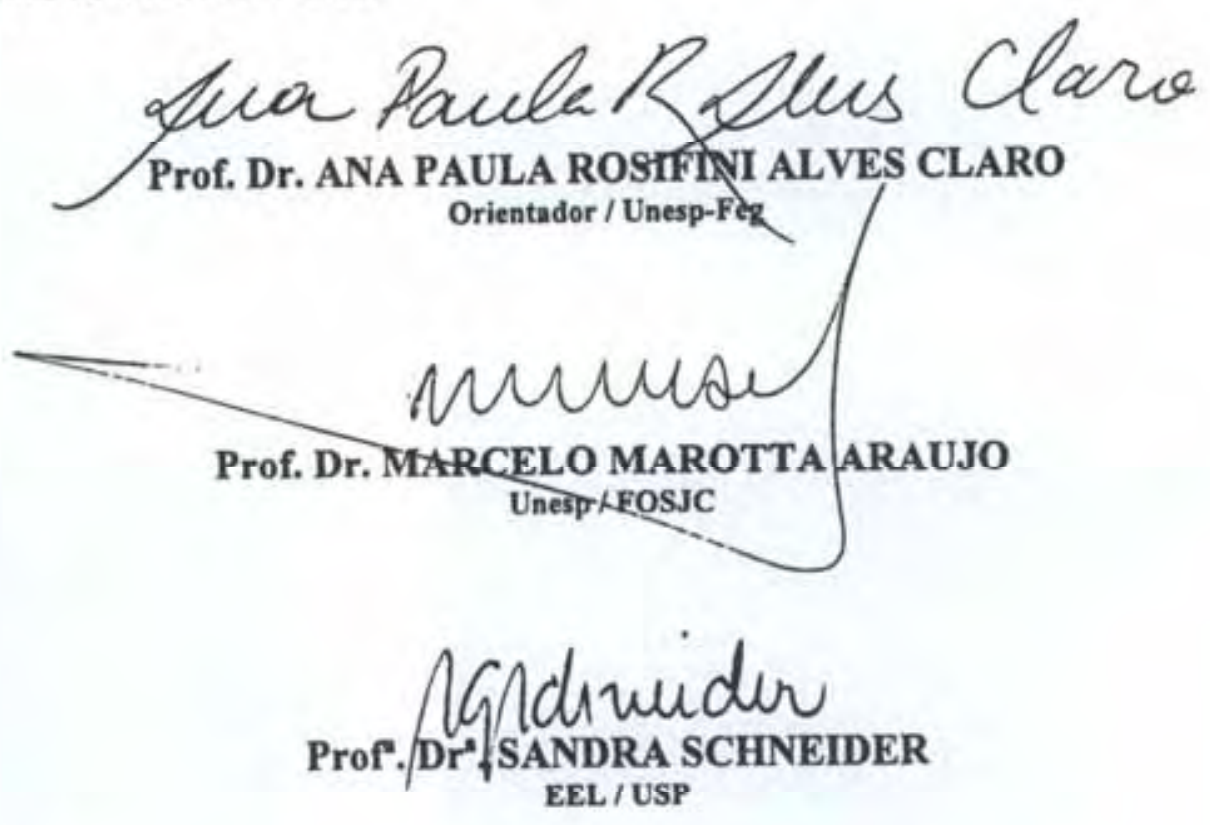


DADOS CURRICULARES

\title{
MARIA ISABEL ÉBOLI KIMAID
}

\author{
NASCIMENTO 12.06.1973 - Guaratinguetá / SP \\ FILIAÇÃO Antonino kimaid \\ Maria da Glória Éboli kimaid \\ 1991/1994 Curso de Graduação em Odontologia \\ Universidade de Taubaté - UNITAU \\ 2008/2010 Curso de Pós-Graduação em Engenharia Mecânica, \\ Nível de Mestrado, na Faculdade de Engenharia \\ do Campus de Guaratinguetá da Universidade Estadual \\ Paulista/ UNESP
}




\section{DEDICATÓRIA}

\section{À Deus,}

pelo dom da vida, me dando coragem nos momentos difíceis, acompanhando e guiando meus passos.

\section{Aos meus pais, Antonino e Maria da Glória,}

pelo amor, carinho, paciência, dedicação e por todas as vezes em que abdicaram de seus sonhos para a realização dos meus. Minha eterna gratidão.

\section{Ao meu filho Luís Fernando,}

por trazer um significado muito maior à minha existência e permitir crescer, a cada dia. 


\section{AGRADECIMENTOS ESPECIAIS}

À minha orientadora Professora Dra. Ana Paula Rosifini Alves Claro , pela oportunidade oferecida, pelos ensinamentos, pela paciência ,pelo incentivo constante e amizade .

Ao Dr. João Paulo Barros Machado do Laboratório de Sensores e Materiais LAS , do Instituto de Pesquisa Espacial(INPE) São José dos Campos , pela dedicação e disponibilidade de realizar todos os ensaios necessários para este trabalho .

À amiga Ana Lúcia do Amaral Escada, pela disponibilidade em sempre ajudar, pelo carinho, atenção e por sua compreensão nos momentos de dificuldades, minha eterna gratidão. 


\section{AGRADECIMENTOS}

Ao Departamento de Materiais e Tecnologia da Engenharia Mecânica da FEG UNESP, pelas informações recebidas, apoio e incentivo, tornando possível a realização dessa dissertação de Mestrado.

Ao Prof. Dr. Marcelo dos Santos Pereira pela colaboração na realização deste estudo.

Aos professores e técnicos do Laboratório de Materiais e Tecnologia da FEG/UNESP, especialmente Domingos Hasmann Neto, José Manoel Bernardes, pela dedicação e cooperação nos trabalhos.

Aos funcionários da Seção de Pós-Graduação da FEG/UNESP, Regina Célia Galvão Faria Alves, Sidney Eustáquio Ramos Rabelo, Maria Cristina Silva de Oliva, Juliana Casella pela atenção no atendimento.

À secretária do Departamento de Materiais e Tecnologia Maria Aparecida R. Vasconcelos pela amizade e gentileza no atendimento.

Às minhas amigas Kamila Amato e Andréia Cecília May Guimarães pelo apoio, pela amizade e colaboração nos ensaios.

Aos alunos da graduação da Iniciação Científica: Flávia Yumi, Gustavo Bartelega, Guilherme Faria e Guilherme Monéia e Tales , que muito se esforçaram para me ajudar nos experimentos. 
Este trabalho contou com o apoio da Coordenação de Aperfeiçoamento de Pessoal de Nível Superior - CAPES - Brasil 
"É melhor tentar e falhar, que preocupar-se e ver a vida passar;

é melhor tentar, ainda que em vão, que sentar-se fazendo nada até o final.

Eu prefiro na chuva caminhar, que em dias tristes em casa me esconder.

Prefiro ser feliz, embora louco, que em conformidade viver..."

\section{Martin Luther King}


KIMAID, M. I. E. Crescimento da Nanoapatita na Liga Ti-30Ta para Aplicações Odontológicas. 2010, Dissertação (Mestrado em Engenharia Mecânica) - Faculdade de Engenharia, Campus de Guaratinguetá, São Paulo, Guaratinguetá, 2010.

\section{RESUMO}

O objetivo deste trabalho foi avaliar a capacidade de formação da apatita na superfície da liga Ti-30TA após modificação da superfície usando o método biomimético com tipos de solução SBF diferentes, convencionais e condensado (5xSBF). A liga Ti-30TA foi obtida a partir do titânio C.P. titânio e tântalo usando um forno de arco voltaico. Os lingotes foram submetidos a um tratamento térmico e foram forjados à frio. $\mathrm{O}$ tarugo foi usinado em um torno $\mathrm{CNC}$ para atingir microestrutura e morfologia semelhante aos implantes dentários. Foram cortados discos com $13 \mathrm{~mm}$ de diâmetro e $3 \mathrm{~mm}$ de espessura. Para o tratamento de superfície, as amostras foram imersas em solução aquosa de $\mathrm{NaOH} \quad 0,5 \mathrm{M}$ a $60^{\circ} \mathrm{C}$ por 24 horas, lavados com água destilada e seco a $40^{\circ} \mathrm{C}$ por $24 \mathrm{~h}$. Após o tratamento alcalino, as amostras foram tratadas termicamente a $300^{\circ} \mathrm{C}$ por $1 \mathrm{~h}$ em um forno elétrico no ar. Os discos foram imersos em SBF para formar uma camada de apatita sobre sua superfície. As superfícies foram avaliadas por microscopia eletrônica de varredura (MEV) e microscopia de força atômica (AFM). Medidas de ângulo de contato foram realizadas a fim de avaliar a molhabilidade. Os resultados indicam a formação de um revestimento de nanoapatita sobre a superfície da liga experimental Ti-30Ta.

Palavras chaves: Implantes dentários; Liga Ti-30Ta; Tratamentos superficiais; Tratamento químico; Tratamento térmico 
KIMAID, M. I. E. Nanoapatite growth in Ti-30Ta alloy for dental use. 2010, Dissertation (Master in Mechanical Engineering) - College of Engeneering, Campus of Guaratinguetá, São Paulo State University, Guaratinguetá, 2010.

\begin{abstract}
The purpose of this work was to evaluate apatite forming ability in surface of Ti30Ta alloy after modification surface using biomimetic method with different SBFs, conventional and condensed (5xSBF). Ti-30Ta alloy was obtained from C.P. titanium and tantalum by using an arc-melting furnace. Ingots were submitted to heat treatment and they were cold worked by swaging. Billet turning on a CNC lathe in order to achieve microstructure and morphology similar to dental implants. Discs with $13 \mathrm{~mm}$ in diameter and $3 \mathrm{~mm}$ in thickness were cutting. For surface treatment, samples were immersed in $0.5 \mathrm{M} \mathrm{NaOH}$ aqueous solution at $60^{\circ} \mathrm{C}$ for 24 hours, washed with distilled water and dried at $40^{\circ} \mathrm{C}$ for $24 \mathrm{~h}$. After the alkaline treatment, samples were heat treated at $300{ }^{\circ} \mathrm{C}$ for $2 \mathrm{~h}$ in an electrical furnace in air. Discs were soaking in SBF to form an apatite layer on the surface. Surfaces were investigated using scanning electron microscope (SEM) and atomic force microscopy (AFM). Contact angle measurements were carried out in order to evaluate the wettability. The results indicate that nanoapatite coating could form on surface of Ti30Ta experimental alloy.
\end{abstract}

Keywords: Titanium - tantalum alloy; Implant material; Surface modification; Chemical treatment; Thermal treatment 


\section{LISTA DE FIGURAS}

FIGURA 1.1 Fragmento de mandíbula encontrado em escavações dos Maias.

FIGURA 1.2 Detalhe da câmera de titânio instalada por Branemark no fêmur de coelho

FIGURA 1.3 Dependência de várias reações com a energia de superfície.

FIGURA 2.1 Estrutura cristalina e parâmetros de rede encontrados para o titânio

FIGURA 2.2 Influência dos elementos de liga sobre os diagramas de fase das ligas de titânio

FIGURA 2.3 Diagrama de Fases Ti-Ta.

FIGURA 2.4 Representação esquemática do mecanismo de formação de apatita em Ti imerso SBF.

FIGURA 3.1 Representação esquemática da metodologia empregada no desenvolvimento da pesquisa: (a) Obtenção das amostras; (b) Modificação da superfície; (c) caracterização da superfície.

FIGURA 3.2 Forno a arco voltaico empregado no preparo das ligas........ 50

FIGURA 3.3 Forno tubular empregado para homogeneização das ligas.

Detalhe do lingote encapsulado a vácuo.

FIGURA 3.4 Equipamento para forjamento à frio FENN e os martelos.

FIGURA 3.5 Detalhe do tarugo preso a castanha do torno antes da usinagem 52

FIGURA 3.6 Banho termostatizado (TE 184, Tecnal).............................. 53

FIGURA 3.7 Forno EDG com aquecimento por resistência elétrica......... 54

FIGURA 3.8 Preparo do SBF com inserção de $\mathrm{CO}_{2}$ (a) inicio e (b) final do preparo 
FIGURA 3.9 Detalhe das amostras imersas em SBF utilizando funil para homogeneização do depósito da apatita............................... 56

FIGURA 3.10 (a) Representação esquemática da amostra no tubo Falcon;

(b) montagem dos tubos em uma mesa agitadora 56

FIGURA 3.11 Microscópio eletrônico de varredura empregado para análise da superfície......................................................... 57

FIGURA 3.12 Equipamento empregado para medida do ângulo de contato....... 59

FIGURA 3.13 Microscópio de força atômica empregado para análise da superfície..................................................................... 60

FIGURA 4.1 Micrografia obtida para amostras após usinagem ............... 62

FIGURA 4.2 Superfícies da amostra após tratamento alcalino e térmico.. 63

FIGURA 4.3 Superfícies da amostra de Ti-30Ta após imersão em SBF com Tris por 7 dias (a) e por 14 dias (b).............................. 64

FIGURA 4.4 Superfícies da amostra de Ti-30Ta após imersão em SBF com $\mathrm{CO}_{2}$ por 1 dia.

FIGURA 4.5 Imagens obtidas a partir de microscopia de força atômica: (a) após imersão em SBF por 07 dias;(b) após imersão em SBF por 14 dias

FIGURA 4.6 Imagem obtida a partir de microscopia de força atômica após imersão em solução SBF por 1 dia $\left(\mathrm{com}^{-1} \mathrm{CO}_{2}\right) \ldots \ldots \ldots \ldots . . . .67$

FIGURA 4.7 Imagem da gota de água sobre a amostra de Ti-30Ta: (a) amostra controle usinado; (b) amostra após tratamento alcalino e térmico; (c) amostra após recobrimento com apatita............................................................... 68

FIGURA $4.8 \quad$ Figura 4.8 - Difratogramas de raios X................................... 70 


\section{LISTA DE QUADROS}

QUADRO 2.1 Classificação dos biomateriais baseada na sua interação com o meio biológico (adaptado GEETHA et al., 2009).....

QUADRO 2.2 Principais propriedades do titânio CP e tântalo CP.............. 33

QUADRO 2.3 Propriedades mecânicas de ligas Ti-Ta................................. 35

QUADRO 2.4 Propriedades mecânicas da liga Ti-30Ta e alguns biomateriais típicos (adaptado de ZHOU et al., 2009)........ 35

QUADRO 2.5 Concentração iônica do plasma sangǘneo humano e

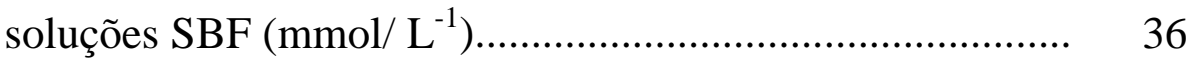

QUADRO 2.6 Composição inorgânica do Plasma humano, fluido corpóreo simulado (SBF) e soluções para revestimentos SBF-A e SBF-B

QUADRO 2.7 Composição de soluções corpórea simulada........................... 39

QUADRO 2.8 Ocorrências de fosfatos de cálcio em sistemas biológicos... 43

QUADRO 2.9 Relação Ca/P das fases de apatita.......................................... 44

QUADRO 3.1 Composição SBF 5x......................................................... 54

QUADRO 4.1 Medidas de ângulo de contato................................................ 67 


\section{SUMÁRIO}

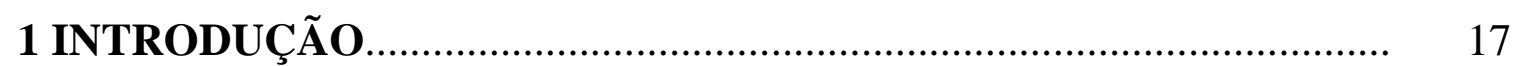

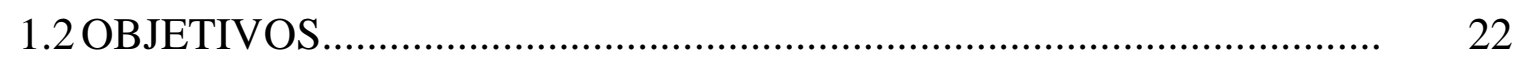

1.3 ESTRUTURA DA DISSERTAÇÃO....................................................... 22

2 REVISÃO DE LITERATURA............................................................. 23

2.1 CONSIDERAÇÕES GERAIS............................................................ 23

2.2 OSSEOINTEGRAÇÃO........................................................................ 25

2.2.1 Mecanismos da osseointegração......................................................... 26

2.3 TITÂNIO E SUAS LIGAS PARA APLICAÇÕES BIOMÉDICAS......... 28

2.3.1 Titânio comercialmente puro (Ti CP)................................................. 29

2.3.2 Classificação das ligas de titânio.......................................................... 31

2.3.3. Tântalo CP....................................................................................... 33

2.3.4. Sistema Ti-Ta ........................................................................

2.4 MODIFICAÇÕES DE SUPERFÍCIE EMPREGANDO O MÉTODO

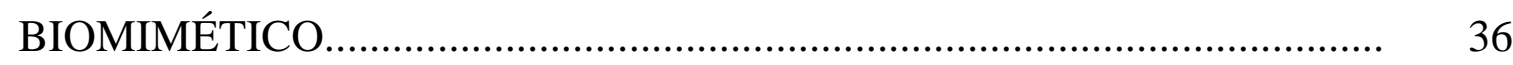

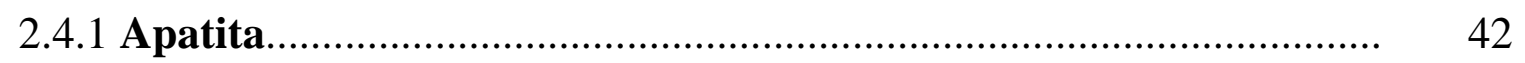

3 MATERIAIS E MÉTODOS ............................................................ 49

3.1 PROCESSAMENTO DAS LIGAS..................................................... 50

3.2 USINAGEM DOS DISCOS............................................................... 52

3.3 MODIFICAÇÃO DA SUPERFÍCIE..................................................... 53

3.3.1 Tratamento Alcalino.......................................................................... 53

3.3.2 Tratamento Térmico........................................................................ 53

3.3.3 Imersão em SBF ........................................................................

3.4 CARACTERIZAÇÃO DA SUPERFICIE................................................ 57

3.4.1 Microscopia Eletrônica de Varredura................................................. 57

3.4.2 Ângulo de Contato............................................................................ 57

3.4.3 Microscopia de Força Atomica........................................................... 59

3.4.4 Difração de Raio - X...................................................................... 60

4 RESULTADOS E DISCUSSÃO ........................................................... 62 
4.1 MICROSCOPIA ELETRÔNICA DE VARREDURA.................. 62

4.2 MICROSCOPIA DE FORÇA ATÔMICA …..................................... 66

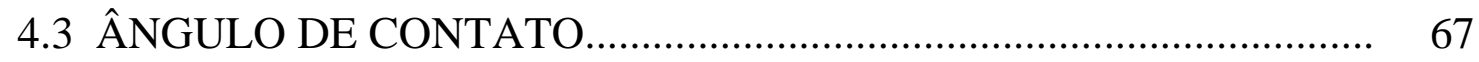

4.4 DIFRAÇÃO DE RAIO-X.......................................................... 69

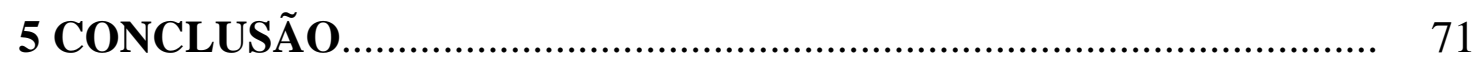

5.1 SUGESTÃO PARA TRABALHOS FUTUROS ....................... 71

6 REFERÊNCIAS BIBLIOGRÁFICAS ............................................ 72 


\section{INTRODUÇÃO}

A perda dos elementos dentários e sua substituição tem sido uma preocupação milenar. Historicamente, alguns povos antigos se destacavam por tentarem artesanalmente suprir essas perdas dentárias confeccionando implantes com fios de fibras e dentes naturais extraídos de cadáveres ou de animais, assim como artefatos metálicos, pedras e conchas na tentativa de substituir os dentes perdidos (Figura 1.1) (CESCHIN,1984).

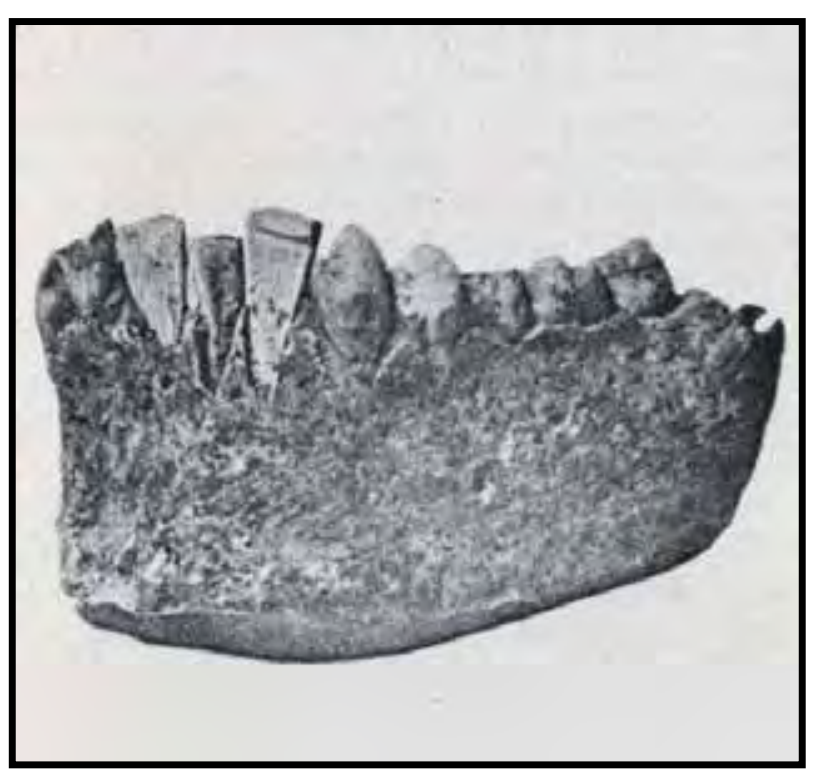

Figura 1.1 - Fragmento de mandíbula encontrado em escavações dos Maias (CESCHIN, 1984)

O grande avanço na implantodontia oral foi alcançado em 1952 no laboratório de microscopia vital da Universidade de Lund, na Suécia, por uma equipe de pesquisadores suecos coordenados por Bränemark (1977), um cirurgião ortopédico. Em uma de suas pesquisas ele estudou a cicatrização óssea em coelhos, empregando uma câmera óptica confeccionada com titânio, a qual era aparafusada no osso do fêmur para facilitar a observação da osteogênese (figura 1.2). Após alguns meses, eles observaram que o cilindro de titânio estava fixo fortemente ao osso, denominando este fenômeno de osseointegração. A partir desse trabalho, Bränemark direcionou suas pesquisas para a aplicação do titânio em osso humano. O titânio foi utilizado em forma de parafuso, e incluído no osso como âncora em regiões de perda dentária, 
observando-se que sob condições controladas, poderia ser estruturalmente integrado ao osso com alto grau de previsibilidade, sem inflamação tecidual ou rejeição em humanos, reafirmando o conceito de osseointegração (CESCHIN, 1984).

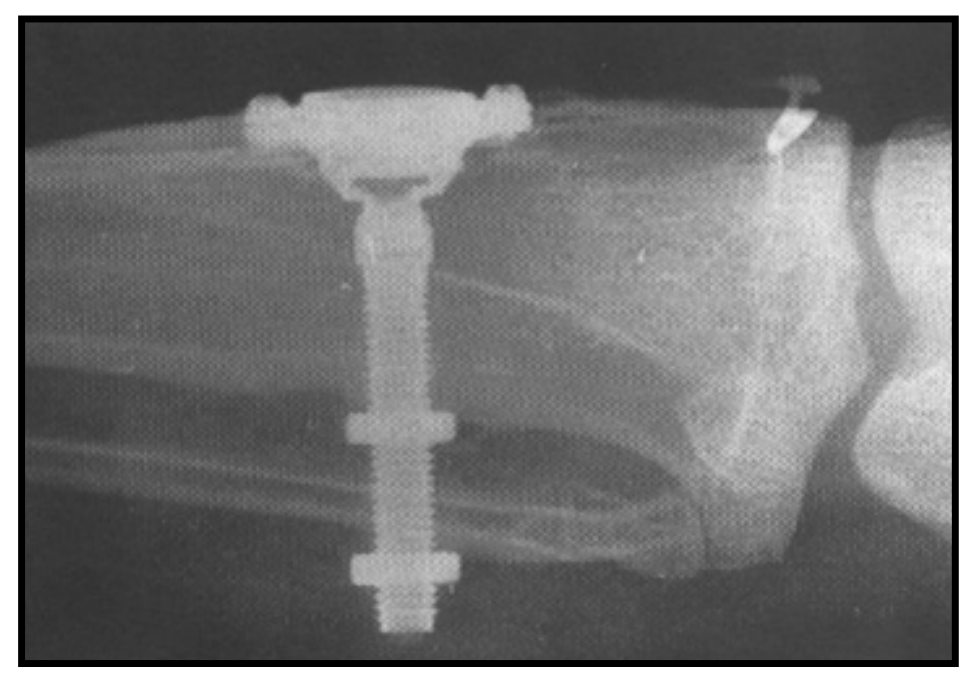

Figura 1.2 - Detalhe da câmera de titânio instalada por Branemark no fêmur de coelho (Branemark , 1977)

A osseointegração é definida como uma ancoragem direta do osso a superfície do implante sob a ação de cargas funcionais, sem a formação de uma camada fibrosa em torno do osso (JONES, 2001). Assim que o implante é fixado dentro do osso, diversas reações biológicas ocorrem em vários estágios. Inicialmente, existe uma adsorção das moléculas de água e proteínas e então um dos seguintes processos tomará lugar (GEETHA et al., 2009):

1. formação de células ósseas novas sobre a superfície do implante, com proliferação de células ósseas e diferenciação, levando a osseointegração;

2. resposta inflamatória do corpo humano ocorrendo à rejeição do implante;

3. micromovimentação do implante levando a formação de tecido fibroso ao invés de interface óssea, impedindo a osseointegração.

O processo que ocorrerá dependerá das propriedades da superfície tais como superfície química, topografia, rugosidade de superfície e principalmente a energia de superfície. A dependência das interações celulares sobre a energia de superfície é ditada pelas varias propriedades de superfície (Figura 1.3). Entretanto, a influência da 
energia de superfície sobre a diferenciação celular, produção da matriz celular e calcificação não é bem compreendida (GEETHA et al., 2009).

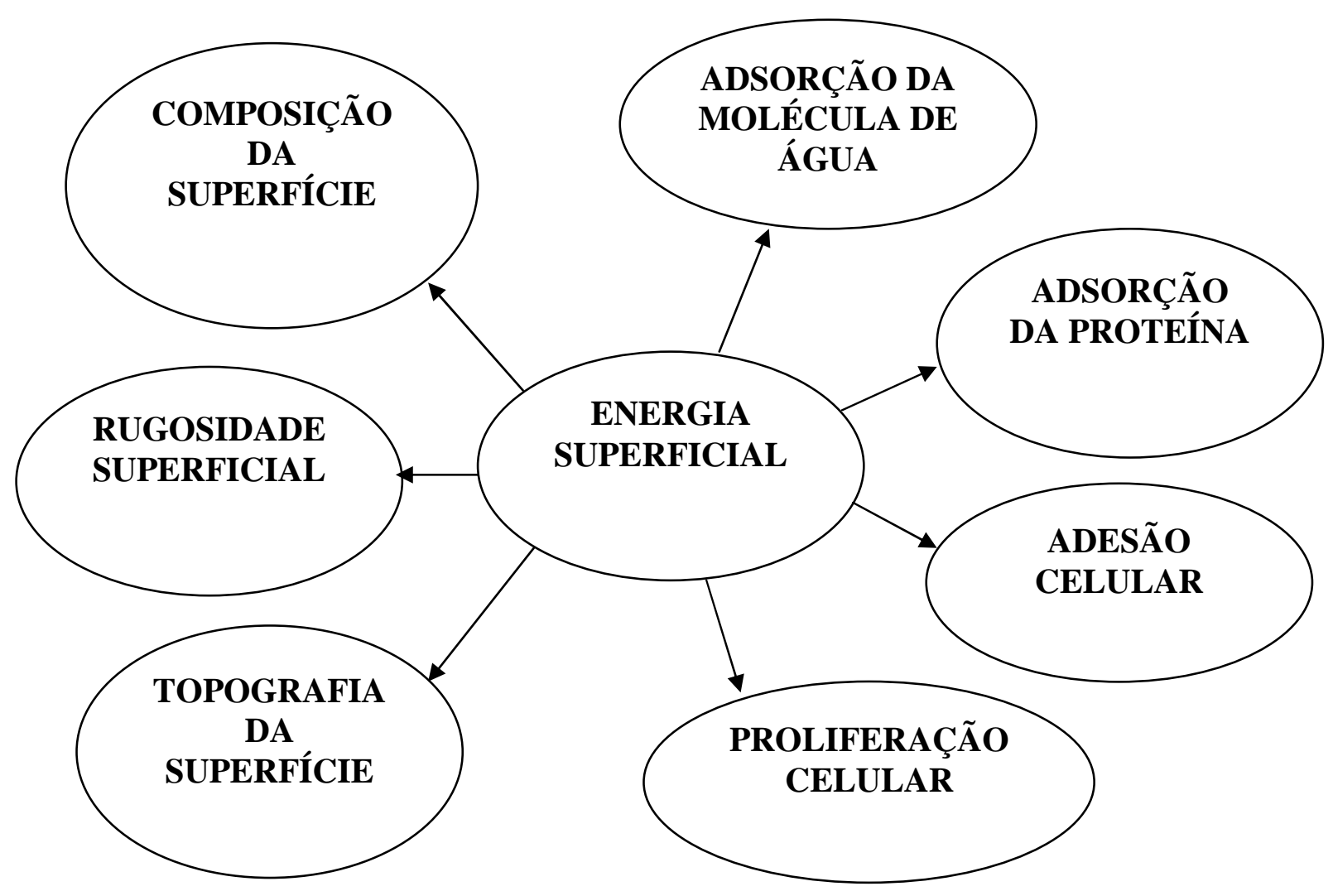

Figura 1.3 - Dependência de várias reações com a energia de superfície (adaptado GEETHA et al., 2009)

Atualmente, o titânio comercialmente puro (Ti CP) e suas ligas são os materiais mais comuns utilizados na fabricação de implantes dentários, por serem materiais com elevada biocompatibilidade e resistência à corrosão (BALAZIC et al., 2007). A biocompatibilidade dos implantes de titânio é atribuída à camada de óxido (3-10nm) que se forma espontaneamente quando o titânio é exposto ao oxigênio. No entanto, esses materiais são considerados bioinertes, ou seja, a união que existe entre esses materiais e o tecido ósseo é mecânica e não química, o que exige um longo período 
para a osseointegração, levando muitas vezes a perda do implante devido a movimentação da interface osso-implante (XUE et al., 2005).

Dessa forma, diversas técnicas de modificações de superfície estão sendo propostas com o intuito de criar uma superfície bioativa para a melhoria da osseointegração. Duan e Wang (2006) classificam as técnicas de modificação de superfície em três categorias a partir das modificações ocorridas na superfície do substrato:

1. adição de materiais com funções desejáveis, empregando técnicas como deposição física de vapor (PVD) e deposição biomimética;

2. conversão da superfície existente em composições e /ou topografias mais desejáveis, a partir da utilização de implantação iônica ou oxidação eletroquímica;

3. remoção do material existente para criar uma topografia especifica, utilizando lixamento ou ataque ácido da superfície.

Outra classificação bastante empregada divide as técnicas de modificação de superfície de acordo com o tratamento aplicado em mecânicas, físicas e químicas. Os métodos mais comuns de modificações mecânicas de superfície como usinagem, polimento e jateamento envolvem tratamentos de transformação ou deformação mecânica ou ainda remoção de materiais da superfície (LIU et al., 2004).

Em processos como Plasma spray e deposição física de vapor (Physical Vapor Deposition - PVD) a formação do revestimento não ocorre a partir de reações químicas e sim a partir de processos físicos envolvendo energia térmica, cinética e elétrica. Nos processos com aspersão térmica os materiais são termicamente fundidos e aspergidos na forma de gotas, com elevada velocidade, sobre o substrato (energia cinética). A deposição física de vapor produz o crescimento de um filme a partir da reação da superfície do substrato com o vapor adjacente, que fornece o material para o revestimento na forma de átomos, íons ou moléculas gerados por um alvo. A implantação iônica e a descarga por plasma também são considerados processos de modificação física de superfície (DUAN e WANG, 2006).

As modificações químicas são empregadas para garantir aos implantes características tais como: limpeza e assepsia para o seu uso em cirurgias, eliminação de impurezas do processo de fabricação, rugosidade adequada da superfície visando o 
aumento de biocompatibilidade, obtenção de uma camada homogênea regular de óxido de espessura variável sobre a sua superfície (SENA et al., 2001). Dentre os processos químicos podemos citar: tratamento químico, tratamento eletroquímico (oxidação anódica), deposição por vapor químico, processo biomimético, deposição sol- gel e deposição por eletroforese (LIU et al., 2004).

Uma das técnicas mais promissoras para produção de biomateriais com superfície bioativa é o método biomimético, que é um processo de deposição de apatitas por precipitação , que tenta imitar as condições biológicas , as quais tornam possíveis o recobrimento de superfícies complexas e sensíveis a temperatura (ALMEIDA et al., 2007) .

O método biomimético foi introduzido por Abe et al (1990) para a produção de biomateriais a temperatura ambiente.

Este método baseia-se na imersão do substrato em solução de composição química e pH semelhantes ao plasma sanguíneo e temperatura igual a do corpo .Com este método é possível recobrir a superfície de materiais com geometrias complexas e/ou sensíveis a altas temperaturas (BARRERE et al., 2001).

Este processo permite obter uma camada de fosfato de cálcio na superfície dos implantes de ligas de titânio, aumentando a osseocondutividade, e beneficiando a osseointegração (KIM et al., 2000) .

O método biomimético tem quatro vantagens principais:

- processamento em baixas temperaturas;

- formação de cristais de hidroxiapatita bem semelhantes ao tecido ósseo;

- deposição em implantes com qualquer geometria;

- alta bioatividade e boa reabsorção para sua substituição (KOKUBO et al.,1998).

Este método tem sido empregado em implantes de titânio comercialmente puro (Ti CP), tântalo comercialmente puro (Ta CP) e em algumas ligas como: Ti-7,5Mo, Ti6Al-4V, Ti-13Zr-13Nb. 


\subsection{OBJETIVOS}

O objetivo do presente trabalho foi a partir do emprego de técnicas de modificações de superfície obter a formação de filmes finos de apatita biológica sobre a superfície da liga Ti-30Ta, para aplicação em implantes odontológicos, visando a redução do tempo da osseointegração. Técnicas de caracterização de superfície como microscopia eletrônica de varredura, microscopia de força atômica, difração de Raios $\mathrm{X}$ e ângulo de contato foram empregadas para a caracterização da topografia e do filme formado em cada estágio.

\subsection{ESTRUTURA DA DISSERTAÇÃO}

Este trabalho é composto por cinco capítulos e pelas referências, e seu conteúdo apresenta-se distribuído da seguinte forma:

- capítulo 1 - Introdução: expõe aspectos gerais sobre a dissertação, proposta do trabalho, objetivos e a estrutura da dissertação;

- capítulo 2 - Revisão da Literatura: considerações gerais, titânio e suas ligas para aplicações biomédicas e modificações de superfície empregando o método biomimético;

- capítulo 3 - Materiais e Métodos: processamento das ligas, usinagem dos discos, modificação da superfície, caracterização da superfície;

- capítulo 4 - Resultados e Discussão: apresentação dos resultados alcançados nos experimentos realizados no trabalho e suas respectivas análises, em confronto com outros autores e trabalhos revisados da literatura.

- capítulo 5 - Conclusão: são expostas as conclusões obtidas a partir da avaliação criteriosa dos resultados encontrados neste trabalho. 


\section{REVISÃO DA LITERATURA}

\subsection{CONSIDERAÇÕES GERAIS}

O desenvolvimento de novos materiais capazes de substituir funções desempenhadas pelo corpo humano, devido a traumas ou surgimento de doenças, cresceu nas últimas quatro décadas devido ao aumento da expectativa de vida da população. Devido a sua aplicação, esses materiais são conhecidos como biomateriais, podendo ser de origem natural ou sintética, utilizados por tempo indeterminado na substituição total, parcial ou ainda na reparação de tecidos vivos danificados, para substituir à estrutura biológica perdida ou doente, buscando restabelecer a forma e/ou a função.

Os biomateriais utilizados induzem diferentes respostas do tecido em função do desenvolvimento do tipo de interface implante/osso, podem ser classificados como :

- biotolerantes ou bioinertes: são definidos como aqueles que não são necessariamente rejeitados quando implantados no tecido vivo, mas são envolvidos por uma cápsula fibrosa que o isolam do meio biológico São materiais bem tolerados pelo organismo, pois são menos suscetíveis a causar uma reação biológica adversa devido a sua estabilidade química em comparação com outros materiais. A espessura dessa cápsula fibrosa depende de muitos fatores existente na interface, condições do implante e o tecido (VALLET-REGI., 2001; SYKARAS et al., 2000);

- bioativos: permitem o íntimo contato com o osso, conduzindo a osteogênese , a formação de novo osso e a troca de íons com o tecido ósseo. Favorecem a ligação química entre implante/osso (osseointegração), sem a presença da cápsula fibrosa . Quando um material bioativo é implantado no corpo, uma série de reações bioquímicas e biofísicas ocorrem na interface implante/tecido. Podem ainda ser classificados como osteoindutores, que promovem uma resposta intracelular e extracelular na interface, e os osteocondutores, que promovem uma superfície biocompatível , favorecendo o desenvolvimneto das células ósseas (VALLET-REGI., 2001; SYKARAS et al., 2000 ). 
- bioabsorvíveis: degradam-se gradualmente ao longo de um período de tempo e são substituídos pelo tecido natural do hospedeiro. Esses materiais são fagocitados pelo organismo após certo período em contato com o tecido. Possuem papel importante em aplicações clínicas, pois são desnecessárias novas intervenções cirúrgicas para a retirada do material (VALLET-REGI, 2001; NARAYANAN et al., 2007).

O Quadro 2.1 mostra a classificação dos biomateriais baseada na sua interação com o meio biológico (adaptado GEETHA et al., 2009).

Quadro 2.1 - Classificação dos biomateriais baseada na sua interação com o meio biológico (adaptado GEETHA et al., 2009)

\begin{tabular}{|c|c|c|c|}
\hline CLASSIFICAÇÃO & RESPOSTA & EXEMPLOS & EFEITO \\
\hline $\begin{array}{c}\text { Materiais } \\
\text { biotolerantes ou } \\
\text { bioinertes }\end{array}$ & $\begin{array}{l}\text { - Formação de tecido } \\
\text { conjuntivo fino } \\
\text { - A cápsula não adere a } \\
\text { superfície do implante }\end{array}$ & $\begin{array}{c}\mathrm{Ti} \\
\mathrm{Ti}-7,5 \mathrm{Mo} \\
\text { Ti-30Ta } \\
\text { CoCr }\end{array}$ & Rejeição do implante \\
\hline $\begin{array}{l}\text { Materiais } \\
\text { Bioativos }\end{array}$ & $\begin{array}{l}\text { Formação de tecido ósseo } \\
\text { em torno do implante e } \\
\text { fortemente integrado com a } \\
\text { superfície do implante }\end{array}$ & $\begin{array}{l}\text { Biovidro, fosfato de } \\
\text { cálcio sintético }\end{array}$ & $\begin{array}{l}\text { Aceitação do } \\
\text { implante }\end{array}$ \\
\hline $\begin{array}{c}\text { Materiais } \\
\text { bioreabsorvíveis }\end{array}$ & $\begin{array}{l}\text { Substituição por tecido } \\
\text { autólogo }\end{array}$ & $\begin{array}{l}\text { Ácido polilático, e } \\
\text { poliglicol enxertos } \\
\text { ósseos processados. }\end{array}$ & $\begin{array}{l}\text { Aceitação do } \\
\text { implante }\end{array}$ \\
\hline
\end{tabular}

Um biomaterial sintético ideal como substituto ósseo, além de provocar uma reação fibrosa mínima, deve ser bioativo , capaz de levar à neoformação óssea e troca de íons com o tecido ósseo. Mecanicamente, deve apresentar resistência similar ao tecido ósseo que está sendo substituído. Deve também possuir características de superfície favoráveis para o depósito de tecido ósseo em um processo denominado osseocondutividade (GIANNOUDIS, DINOPOULOS, TSIRIDIS., 2005). 


\subsection{OSSEOINTEGRAÇÃO}

O conceito de osseointegração foi desenvolvido por Branemark, que descobriu uma ancoragem óssea direta, forte, de uma câmera de titânio usada para estudo da microcirculação em mecanismos de reparação óssea, observando que a câmera de titânio estava cirurgicamente inserida na tíbia de um coelho. A partir dessa observação a osseointegração foi definida como uma ancoragem de um corpo implantado diretamente no osso, o qual permite ao osso suportar uma prótese. O implante tem a possibilidade de transmitir forças oclusais diretamente ao osso. Isto significa que o implante deve ser feito de material inerte para estar em contato direto com o tecido ósseo, sem interferência de tecido mole (mucosa) (Todescan et al., 2005).

Os estudos que se seguiram envolveram implantes de titânio colocado em mandíbulas de cães e os resultados foram avaliados em diferentes intervalos de tempo. Depois de um ano, foram feitas dissecações de segmentos de osso para exame ao microscópio. Havia inflamação discreta nos tecidos ao redor do implante, que não se estendeu ao tecido ósseo. O tecido que circundava o implante foi identificado como sendo similar ao epitélio juncional, com estruturas características como as encontradas em seres humanos (Todescan et al., 2005).

Os fatores que influenciam o sucesso da osseointegração foram devidamente examinados e o primeiro fator é pertinente às características do material. Quando o implante de titânio entra em contato com a atmosfera, forma-se imediatamente uma camada de óxido, com espessura entre 50 - 100 angstroms. Quando o implante está devidamente cicatrizado no osso, a camada de óxido é circundada por uma camada de glicoproteínas e uma camada calcificada de aproximadamente 100 angstrom de espessura. Antes da colocação do implante no osso, a superfície do titânio deve ser mantida estéril, e o contato com outros metais ou substâncias protéicas deve ser evitado (Todescan et al., 2005).

O segundo fator está ligado ao desenho do implante. Ele tem superfície rosqueada e é colocado dentro do osso preparado e com rosca. As roscas criam uma área aumentada e também ajudam a balancear a distribuição de forças ao redor do tecido ósseo e tem papel importante na fixação inicial do implante. Se houver grande 
folga entre as roscas ósseas e o implante, pode ocorrer proliferação de tecido mole, em vez de uma interface óssea direta. O encaixe inicial do implante auxilia a estabilidade em circunstâncias como densidade óssea pobre como na maxila (Todescan et al., 2005).

O terceiro fator refere-se à prevenção da excessiva produção de calor durante a perfuração óssea. $\mathrm{O}$ osso não pode ser aquecido além de $43^{\circ} \mathrm{C}$ para que sua vitalidade seja mantida. Quando a temperatura excede $43^{\circ} \mathrm{C}$, a fosfatase alcalina entra em colapso, o ideal é que a temperatura não exceda a $39^{\circ} \mathrm{C}$.

O quarto fator refere-se à necessidade de manter os implantes dentro do osso sem forças ou cargas oclusais sobre eles. É necessário que os implantes fiquem em repouso por seis meses na maxila e por três a quatro meses na mandíbula. (Todescan et al., 2005).

\subsubsection{Mecanismos da osseointegração}

Após a implantação no organismo humano, o implante é recoberto inicialmente por neutrófilos e macrófagos podendo ocorrer a formação de células gigantes a partir dos macrófagos ativados, podendo ocorrer uma reação de corpo estranho e consequentemente o comprometimento do implante. Além disso, a liberação de citocínas pelos macrófagos atrai fibroblastos, que realizam a encapsulação do processo. Simultaneamente, células osteoprogenitoras migram para o local de inflamação e se diferenciam em osteoblastos produzindo osso. Após o implante ser exposto à matriz óssea e ao fluido extracelular, ocorre a interação com a água e íons, e a partir desta reação, havendo adsorção de proteínas não-específicas. Posteriormente, proteínas não-colagenosas e fatores de crescimento são ativadas e liberadas, vindas

primeiramente da circulação sanguínea e, dos fluidos teciduais e tardiamente da atividade celular da região, sendo responsáveis pela reparação (LIU et al., 2004).

O processo de cicatrização do implante é similar a cicatrização primária do osso. Inicialmente o sangue está presente entre o implante e o osso formando-se coágulo sanguíneo. Este é transformado em tecido de granulação com células fagocitárias, 
como os leucócitos, polimorfonucleares, células linfóides e macrófagos. A atividade fagocitária atinge o nível máximo entre o primeiro e o terceiro dia após a cirurgia. Durante este período ocorre a formação de tecido de granulação e do pré-calo, contendo fibroblastos, tecido fibroso e fagócitos. O pré-calo se transforma em tecido conjuntivo denso e células mesenquimais se diferenciam em osteoblastos e fibroblastos. O tecido conjuntivo formado é chamado de calo, incluindo osteoblastos que aparecem na superfície do implante. Fibras osteogênicas formadas por osteoblastos têm um potencial de calcificação. O tecido conjuntivo denso forma então um calo fibrocartilaginoso, que ocorre normalmente entre o implante e o osso. O osso neoformado penetra e a nova matriz óssea é chamada de calo ósseo. O novo osso amadurece aumentando em densidade e dureza, desaparecendo nesta fase a figura do calo. Nesta fase, a prótese pode ser apoiada nos implantes, e sob estímulo ocorre a remodelação óssea (PAIVA et al., 2005).

A osseointegração desenvolve-se em três estágios: inicialmente é depositado um tecido ósseo imaturo que usualmente se origina do tecido adjacente em direção à superfície do implante; a partir do segundo mês o deposito de um tecido ósseo lamelar dentro de um mês, o estágio de remodelação óssea se inicia com eventos simultâneos de reabsorção óssea pelos osteoclastos e de formação por osteoblastos (SCHENK e BUSER., 1998).

As primeiras fases da osseointegração estão diretamente relacionadas com a adesão e o espalhamento das células. A adesão depende de eventos que ocorrem em curto prazo, como as ligações físico-químicas entre as células e o material (formas iônicas, formas de Vander Wals), além disso, depende de eventos em longo prazo, envolvendo moléculas biológicas, como células, proteínas, entre outros. A qualidade desses eventos irá influenciar a capacidade de proliferação das células em contato com o implante (JONES et al., 2001).

A estrutura do osso circundante é responsável por modificações na resposta tecidual aos diferentes tipos de implantes, principalmente no que diz respeito à estabilidade primária. O osso compacto, onde o volume da densidade da matriz óssea é de aproximadamente 80 a $90 \%$, é o tecido que mais contribui para a estabilidade primária. Nas regiões corticais, a estabilidade é obtida pela fixação direta do implante 
ao osso, porém, a pressão exercida pela colocação do implante promove deformação plástica das lamelas, compressão e ruptura de vasos sanguíneos, com conseqüente necrose de algumas áreas. Por meio da remodelação óssea as áreas avasculares são substituídas por tecido ósseo maduro. O osso esponjoso que apresenta um volume de densidade da matriz óssea de somente 20 a $25 \%$ contribui muito pouco para a estabilidade primária. Por outro lado, uma grande área da superfície do implante fica exposta a medula óssea, onde existe ampla vascularização e muitas células precursoras de osteoblastos (SCHENK e BUSER., 1998).

A formação óssea em torno do implante é muito complexa, pois algumas estruturas precisam ser consideradas, como a superfície óssea, tecido ósseo neoformado na interface implante/osso e a superfície do implante (SCHENK e BUSER., 1998).

Dentre os biomateriais metálicos empregados em implantodontia, o titânio é um dos mais utilizados, devido as suas excelentes propriedades mecânicas e estabilidade química quando inserido no corpo humano (SPRIANO, 2005).

\subsection{TITÂNIO E SUAS LIGAS PARA APLICAÇÕES BIOMÉDICAS}

Nas ultimas décadas titânio CP foi amplamente empregado na substituição de tecidos duros devido as suas excelentes propriedades como biocompatibilidade, baixa densidade $\left(4,54 \mathrm{~g} / \mathrm{cm}^{3}\right)$, elevada resistência mecânica $(785 \mathrm{MPa})$ e elevada resistência à corrosão, a qual é atribuída a uma camada de óxido de titânio $\left(\mathrm{TiO}_{2}\right)$, não estequiométrica, amorfa e formada espontaneamente sobre a superfície quando o metal é exposto ao ar. Outro papel importante desempenhado pela camada passiva a sorção de proteínas, cátions (íons cálcio) e ânions (íons fosfato) sobre a camada (ROHANIZADEH et al., 2004). No entanto, sua aplicação é limitada devido a sua baixa resistência mecânica e limite de resistência à fadiga, o que levou ao emprego de ligas de titânio com propriedades superiores.

A liga Ti-6Al-4V desenvolvida inicialmente para aplicações aeroespaciais, foi amplamente empregada, no entanto, estudos revelando a citotoxicidade dessas ligas 
devido ao emprego de alumínio e vanádio na sua composição promoveu a pesquisa de novas ligas com elementos de ligas como molibdênio, zircônio, tântalo, nióbio, dentre outros (PURCEK et al., 2009).

A avaliação do comportamento biológico de elementos metálicos tem demonstrado que a composição dos biomateriais pode ser ajustada para minimizar as reações teciduais adversas ou alérgicas, resultantes da liberação de íons devido à taxa de corrosão da liga. Estudos demonstraram que elementos como vanádio, níquel e cobalto são considerados citotóxicos enquanto tântalo, zircônio, nióbio e platina são considerados resistentes à corrosão, produzindo óxidos insolúveis (LONG e RACK, 1998).

\subsubsection{Titânio comercialmente puro (Ti CP)}

O titânio é um elemento alotrópico o que significa que ele pode existir em mais de uma forma cristalográfica. A temperatura ambiente exibe a estrutura hexagonal compacta, hcp, (titânio- $\alpha$ ) transformando-se em uma estrutura cúbica de corpo centrado, ccc, a $883^{\circ} \mathrm{C}$ (titânio $\beta$ ), na figura 2.1 é possível observar os respectivos parâmetros de rede. A temperatura de transformação na qual essa mudança ocorre é denominada temperatura de transição $\beta$. (FREESE et al., 2001). 

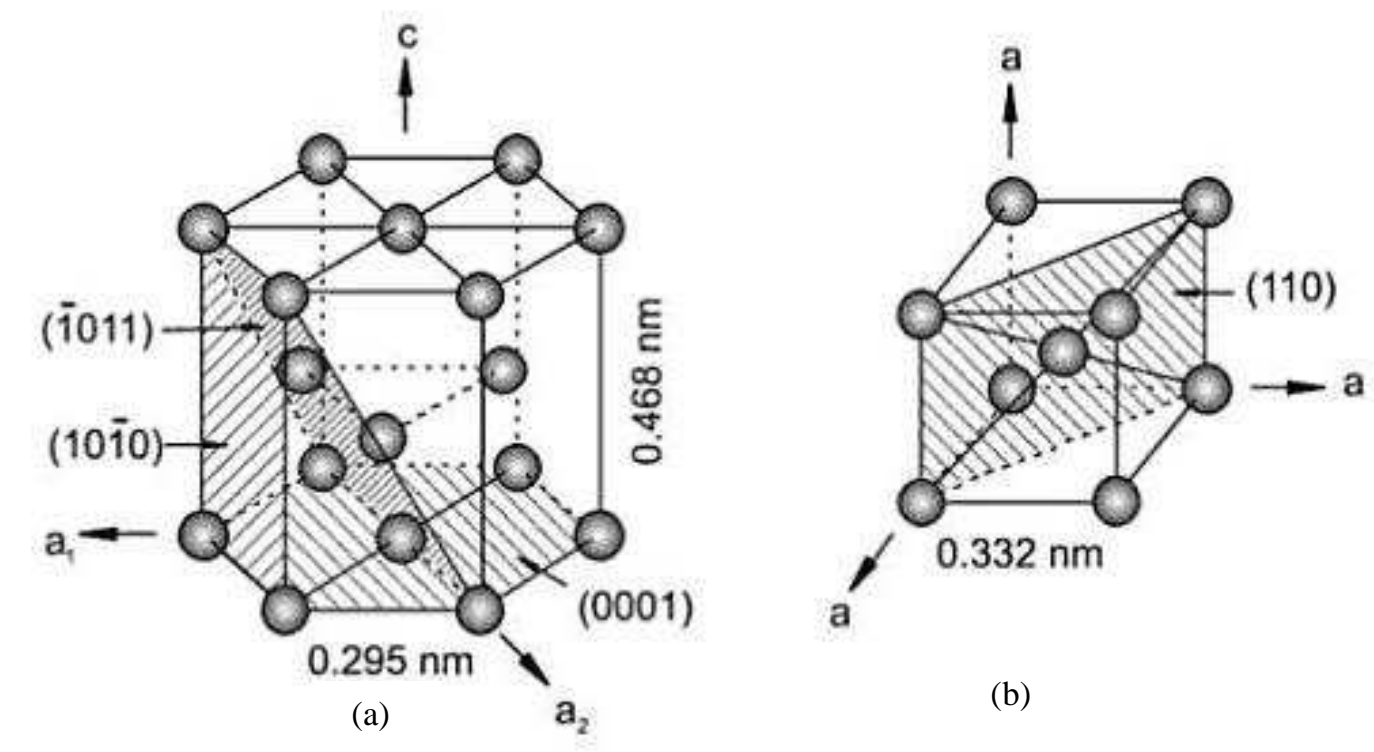

(b)

Figura 2.1 - Estrutura cristalina e parâmetros de rede encontrados para o titânio (PETERS et al., 2003)

De acordo com a norma ASTM o titânio comercialmente puro (Ti CP) pode ser dividido em 5 tipos de acordo com o grau de pureza (elementos residuais oxigênio e ferro):

- Grau 1 (99,5\%p Ti): o Ti CP grau 1 possui o valor de resistência mecânica mais baixo e menor valor de elementos residuais, oxigênio e ferro. $O$ oxigênio age como um endurecedor intersticial mantendo a fase- $\alpha$ hexagonal compacta enquanto o ferro estabiliza a fase $\beta$ (CCC). A baixa quantidade desses elementos diminui a sua resistência mecânica, porem eleva a sua dutilidade conferindo-lhe excelente conformabilidade a frio.

- Grau 2 (99,3\% p Ti): o grau 2 é o mais empregado na industria, apresentando boa dutilidade e resistência mecânica. Sua resistência mecânica é equivalente a apresentada pelo aço inoxidável podendo também ser trabalhado a frio. Apesar da sua ampla utilização na indústria, o TiCP grau 3 e 4 são os mais empregados na odontologia na fabricação de implantes dentários. 
- Grau 3 (99,2 \%p Ti): TiCp grau 3 possui resistência mecânica levemente superior devido ao elevado conteúdo residual (principalmente oxigênio) com dutilidade levemente mais baixa.

- Grau 4 (99,0\%p Ti): o grau 4 possui a maior resistência mecânica dentre todos os tipos, sendo empregado na indústria aeroespacial e biomédica (MOUNTFORD, 2001).

\subsubsection{Classificação das ligas de titânio}

Dependendo da sua influência sobre a temperatura de transição $\beta$, os elementos de liga podem ser classificados em neutros, estabilizadores- $\alpha$ ou estabilizadores- $\beta$ (Figura 2.2). Os elementos estabilizadores- $\alpha$ estendem o campo $\alpha$ para temperaturas elevadas enquanto estabilizadores $\beta$ abaixam a temperatura beta-transus. Os elementos neutros exercem pouca influencia sobre a temperatura $\beta$-transus. Dentre os estabilizadores $\alpha$, o alumínio é considerado o mais importante elemento de liga do titânio. Os elementos intersticiais oxigênio, nitrogênio e carbono também pertencem a esta categoria. Os estabilizadores $\beta$ são subdivididos em $\beta$-isomorfos e $\beta$-eutéticos, sendo a primeira categoria a mais importante devido à elevada solubilidade do molibdênio, vanádio e tântalo nessas ligas. Os estabilizadores $\beta$-eutéticos, como ferro, manganês, cromo, cobalto e níquel, podem levar a formação de compostos intermetálicos. Sn e $\mathrm{Zr}$ são considerados neutros uma vez que não influenciam a fronteira $\alpha / \beta$. 


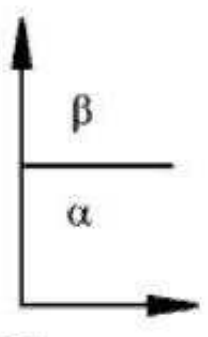

$\mathrm{Ti}$

neutro

$(\mathrm{Sn}, \mathrm{Zr})$

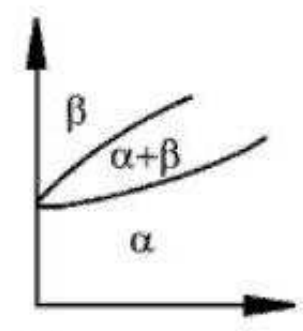

$\mathrm{Ti}$

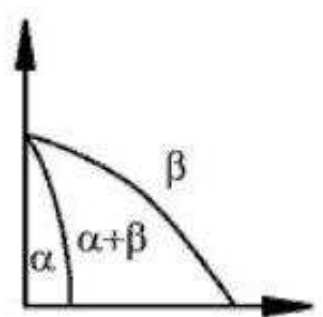

Ti

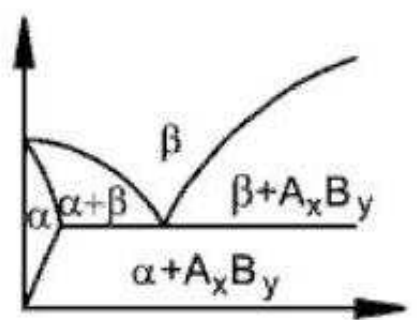

$\mathrm{Ti}$

estabilizador- $\beta$

estabilizador- $\alpha$

$(\mathrm{Al}, \mathrm{O}, \mathrm{N}, \mathrm{C})$ $\beta$-isomorfo

(Mo, V, Ta, Nb) $\beta$ - eutetóide

(Fe, Mn, Cr, Co, Ni, Cu, Si, H)

Figura 2.2 - Influência dos elementos de liga sobre os diagramas de fase das ligas de titânio (adaptado de PETERS et al., 2003)

As ligas de titânio são classificadas como $\alpha, \beta, \alpha+\beta$ e subdivididas em "near- $\alpha$ " e “near- $\beta$ ”. As ligas $\alpha$ são monofásicas e exibem estrutura cristalina hexagonal compacta (hcp). Possuem elevada fluência e não são endurecíveis por tratamento térmico, o que resulta em boa soldabilidade. São empregadas em aplicações criogênicas uma vez que estruturas hcp não exibem transição dútil-frágil (WEISS e SEMIATIN, 1999).

As ligas de titânio $\alpha+\beta$ contém um ou mais elementos $\beta$ estabilizadores em quantidade suficiente para permitir a retenção de apreciável quantidade de fase $\beta$ à temperatura ambiente, resultando em uma microestrutura $\alpha+\beta$.

As ligas "near- $\beta$ ” e $\beta$ são ricas em $\beta$ estabilizadores e são caracterizadas pela alta temperabilidade e elevada resistência à fadiga. Possuem menos $\alpha$ estabilizadores do que as ligas $\alpha$ e $\alpha+\beta$ e uma quantidade suficiente de $\beta$ estabilizadores que evitam a formação da martensita no resfriamento (WEISS e SEMIATIM, 1998). 


\subsubsection{Tântalo CP}

O tântalo é conhecido pela sua excelente tenacidade à fratura e trabalhabilidade. $\mathrm{Na}$ área biomédica é utilizado para suturas e na confecção de placas. No entanto, assim como o titânio são considerados materiais bioinertes e não bioativos (Miyazaki et al., 2002).

No quadro 2.2 podem ser observadas as principais propriedades do titânio CP e tântalo CP.

Quadro 2.2 - Principais propriedades do titânio CP e tântalo CP

\begin{tabular}{|c|c|c|c|}
\hline PROPRIEDADES & \multicolumn{2}{|c|}{ Ti CP } & Ta CP \\
\hline Número atômico & \multicolumn{2}{|c|}{22} & 73 \\
\hline Peso atômico (g/mol) & \multicolumn{2}{|c|}{7,9} & 180,95 \\
\hline \multirow[t]{2}{*}{ Estrutura cristalina } & $\begin{array}{c}\alpha \\
\text { (hcp) }\end{array}$ & \multirow{2}{*}{$\begin{array}{l}c=4,68 \\
a=2,95 \\
a=3,28\end{array}$} & \multirow[t]{2}{*}{$\operatorname{ccc}$} \\
\hline & $\begin{array}{c}\beta \\
(\mathrm{ccc})\end{array}$ & & \\
\hline Densidade $\mathrm{g} / \mathrm{cm}^{3}$ & \multicolumn{2}{|c|}{4,51} & 16,6 \\
\hline Temperatura de fusão $\left({ }^{\circ} \mathrm{C}\right)$ & \multicolumn{2}{|c|}{1650} & $2.996^{\circ} \mathrm{C}$ \\
\hline Coeficiente de expansão térmica, $\alpha$, a $20^{\circ} \mathrm{C}$ & \multicolumn{2}{|c|}{$8,4 \times 10^{-6}$} & $0,63 \times 10^{-5}$ \\
\hline Condutividade térmica (W/mK) & \multicolumn{2}{|c|}{19,2} & 57,5 \\
\hline Módulo de elasticidade, $\alpha,(\mathrm{GPa})$ & \multicolumn{2}{|c|}{105} & 186 \\
\hline
\end{tabular}




\subsubsection{Sistema Ti-Ta}

O diagrama de equilíbrio de fase do sistema Ti-Ta é do tipo isomorfo simples. O equilíbrio das fases no sistema Ti-Ta são: uma solução sólida de estrutura "ccc" ( $\beta$ Ti, Ta) com uma completa e mútua solubilidade acima da temperatura de transição ( $\beta$ Ti) $\leftrightarrow(\alpha \mathrm{Ti})$ do titânio puro $\left(882^{\circ} \mathrm{C}\right)$. Uma solução sólida de estrutura "hcp" $(\alpha \mathrm{Ti})$ em baixa temperatura, com restrita solubilidade. Existem alterações nas propriedades físicas que sugestionam um equilíbrio do composto $\mathrm{Ti}_{3} \mathrm{Ta}$, entretanto estas alterações não são observadas no estudo da microestrutura ou da estrutura cristalina (MURRAY et al., 1997).

Na figura 2.3 é possível observar o diagrama de fases binário Ti-Ta com as fases esperadas para esse sistema. A fase $\alpha$ é esperada para teores de tântalo inferiores a $12 \%$, enquanto a fase $\beta$ ocorre para teores superiores a $50 \%$ p.

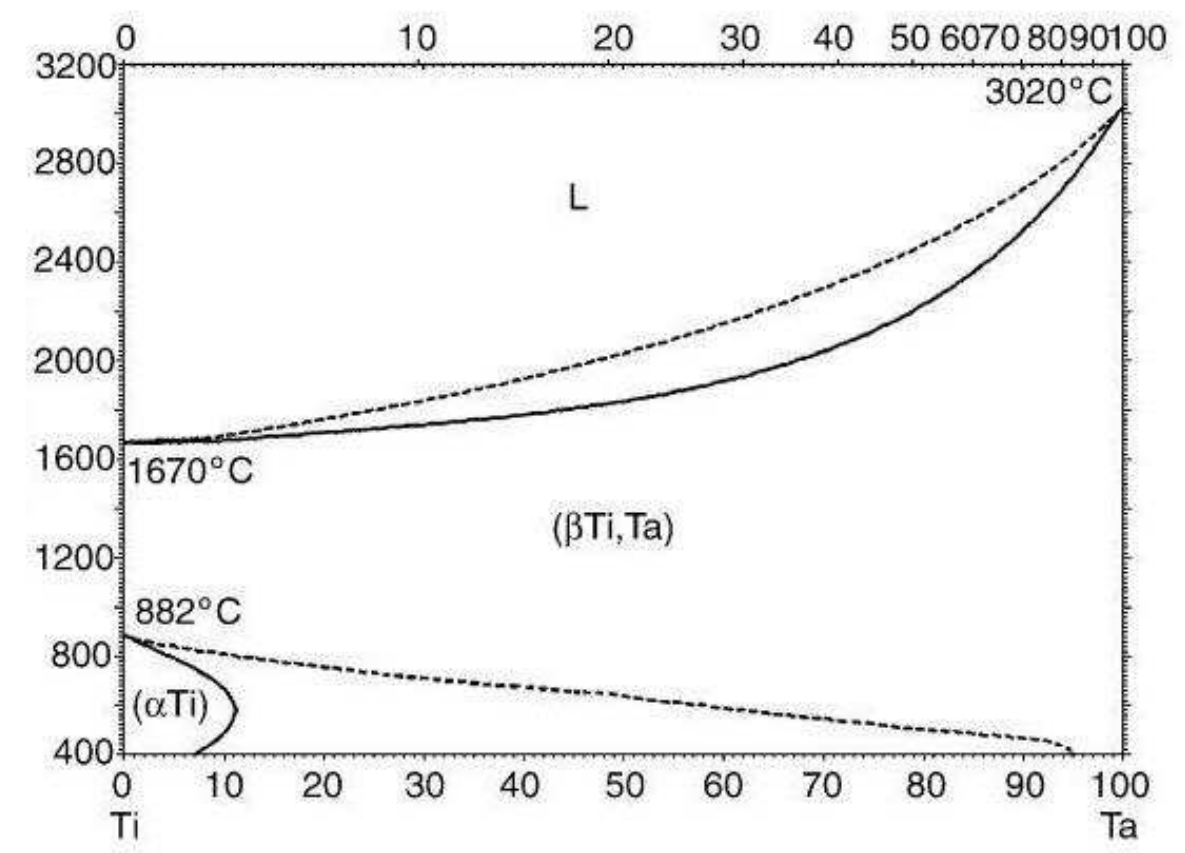

Figura 2.3 - Diagrama de Fases Ti-Ta MASSALSKI (1990 apud SOUZA, 2003)

Estudos realizados por Gibbesch et al., (2000) na década de noventa revelaram que o tântalo proporciona uma melhor adesão da cerâmica ao metal. Em 1997, Prigent 
et al., avaliaram a biocompatibilidade da liga Ti-5Ta e concluíram a viabilidade da sua utilização na área odontológica.

O efeito do conteúdo de tântalo sobre o módulo de elasticidade dinâmico foi avaliado por Zhou et al. (2004). Os autores investigaram as seguintes ligas: Ti-10\% Ta, Ti-20\% Ta, Ti-30\% Ta, Ti-40\% Ta, Ti-50\% Ta, Ti-60\% Тa, Ti-70\% Тa e Ti-80\% Та е concluíram que o teor de tântalo influenciou significativamente os resultados, sendo que as ligas Ti-30Ta e Ti-70Ta exibiram os menores valores de módulo de elasticidade associados à melhor combinação de elevada resistência/baixo módulo, comparadas as outras composições avaliadas (Quadro 2.3). No quadro 2.4 observa-se um breve resumo das propriedades mecânicas da liga Ti-30Ta e alguns biomateriais metálicos.

Quadro 2.3 - Propriedades mecânicas de ligas Ti-Ta (ZHOU et al., 2004)

\begin{tabular}{|c|c|c|}
\hline Liga & $\begin{array}{c}\text { Módulo de elasticidade } \\
(\mathbf{G P a})\end{array}$ & $\begin{array}{c}\text { Limite de resistência } \\
\text { à tração } \\
(\mathbf{M P a})\end{array}$ \\
\hline Ti-10Ta & 99 & 397 \\
\hline Ti-30Ta & $\mathbf{6 9}$ & $\mathbf{4 8 0}$ \\
\hline Ti-40Ta & 81 & 346 \\
\hline Ti-50Ta & 88 & 380 \\
\hline Ti-60Ta & 82 & 504 \\
\hline Ti-70Ta & 67 & 374 \\
\hline Ti-80Ta & 104 & 602 \\
\hline
\end{tabular}

Quadro 2.4 - Propriedades mecânicas da liga Ti-30Ta e alguns biomateriais típicos (adaptado de ZHOU et al., 2009)

\begin{tabular}{|c|c|c|}
\hline Liga & $\begin{array}{c}\text { Módulo de elasticidade } \\
\text { (GPa) }\end{array}$ & $\begin{array}{c}\text { Limite de resistência } \\
\text { à tração } \\
\text { (MPa) }\end{array}$ \\
\hline Ti CP & 103 & $170-485$ \\
\hline Ti-6A1-4V & $110-114$ & $825-869$ \\
\hline Co-Cr-Mo & 220 & 448 \\
\hline 316 & 379 & 793 \\
\hline 316L & 200 & $170-750$ \\
\hline Ti-30Ta & 69 & 480 \\
\hline
\end{tabular}




\subsection{MODIFICAÇÕES DE SUPERFÍCIE EMPREGANDO O MÉTODO BIOMIMÉTICO}

Uma das técnicas mais promissoras empregadas para a deposição de apatita é o método biomimético o qual mimetiza o processo de mineralização do osso humano, resultando no aumento da osseointegração (YAN et al., 1997).

Inicialmente proposto por Kokubo et al., (1998), utiliza uma solução denominada SBF (Simulated Body Fluid) com composição, temperatura e pH similares ao fluido corpóreo.

No quadro 2.5 são mostradas as concentrações iônicas do plasma sangüíneo humano e do SBF proposto por Kokubo (KOKUBO et al.,1998)

Quadro 2.5 - Concentração iônica do plasma sangüíneo humano e soluções SBF $\left(\mathrm{mmol} / \mathrm{L}^{-1}\right)$

\begin{tabular}{|c|c|c|c|c|c|c|c|c|c|}
\hline Soluções & $\mathbf{N a}^{+}$ & $\mathbf{K}^{+}$ & $\mathbf{M g}^{2+}$ & $\mathbf{C a}^{2+}$ & $\mathbf{C l}^{-}$ & $\left(\mathbf{H P O}_{4}\right)^{-2}$ & $\left(\mathbf{H C O}_{3}\right)^{-}$ & $\left.\mathbf{( S O}_{4}\right)^{-2}$ & $\mathbf{C a} / \mathbf{P}$ \\
\hline $\begin{array}{c}\text { Plasma sanguíneo } \\
\text { humano }\end{array}$ & 142,0 & 5,0 & 1,5 & 2,5 & 103,0 & 1,0 & 27,0 & 0,5 & 2,5 \\
\hline SBF original & 142,0 & 5,0 & 1,5 & 2,5 & $\mathbf{1 4 8 , 8}$ & 1,0 & $\mathbf{4 , 2}$ & $\mathbf{0}$ & 2,5 \\
\hline
\end{tabular}

O método de Abe (1990) apud kokubo (2006) consiste em colocar um substrato em uma solução sintética (SBF), de composição iônica semelhante ao plasma sanguíneo. Junto ao substrato coloca-se uma placa de vidro bioativo a cerca de $0,5 \mathrm{~mm}$ deste substrato. Depois de imerso durante 7 dias à $36,5^{\circ} \mathrm{C}$, forma-se no substrato uma camada contínua e homogênea de $1 \mu \mathrm{m}$ de espessura composta por cristalitos de hidroxiapatita semelhante à biológica muito finos e de aparência fibrosa. Após uma nova reimersão por 7 dias em uma solução 1,5 vezes mais concentrada que a primeira, obtém-se um aumento na espessura da camada de até $15 \mu \mathrm{m}$. A caracterização do 
recobrimento demonstrou que se tratava da hidroxiapatita carbonatada de baixa cristalinidade, muito semelhante à da hidroxiapatita biológica presente no tecido ósseo natural (KOKUBO et al., 2006).

Kokubo et.al.(2006) desenvolveu um método de processamento biomimético para implantes de titânio, onde a superfície passa pelo tratamento químico e térmico. A superfície do titânio é recoberta espontaneamente com uma fina camada de óxido de titânio $\left(\mathrm{TiO}_{2}\right)$, tornando-se assim quimicamente estável. Quando os implantes são imersos em solução alcalina $\left(\mathrm{OH}^{-}\right)$há a dissolução da camada de óxido podendo promover a corrosão e formação de grandes poros na superfície do material, por meio da reação: $\mathrm{TiO}_{2}+\mathrm{OH}^{-} \leftrightarrow \mathrm{HTiO}_{3}{ }^{-}$. Assim, quando o titânio e suas ligas são submersos e reagem com solução aquosa $\mathrm{NaOH}$, ocorre incorporação dos íons sódio aos íons $\mathrm{HTiO}_{3}{ }^{-}$formando um gel quimicamente instável, chamado de titanato de sódio $\left(\mathrm{Na}_{2} \mathrm{TiO}_{3}\right)$. O titânio é submetido a tratamento térmico a $600^{\circ} \mathrm{C}$, para a estabilização deste gel ocorrendo a desidratação da camada de titanato de sódio. Esta camada se estabiliza como uma camada de titanato de sódio amorfo contendo pequenas quantidades de titanato de sódio cristalino $\left(\mathrm{Na}_{2} \mathrm{Ti}_{5} \mathrm{O}_{11}\right)$ e rutilo $\left(\mathrm{TiO}_{2}\right)$. Após o tratamento alcalino e térmico, os implantes de titânio são submersos em $\mathrm{SBF}$ a $37^{\circ} \mathrm{C}$, para a formação de uma camada densa e uniforme de apatita na superfície. Primeiramente os íons $\mathrm{Na}^{+}$da camada de titanato formado com o tratamento alcalino e térmico são substituídos por íons $\mathrm{H}_{3} \mathrm{O}^{+}$do $\mathrm{SBF}$ formando grupos Ti-OH na superfície que induzem a formação de apatita. A superfície do metal tratado é inicialmente carregada negativamente $\left(\mathrm{Ti}-\mathrm{OH}^{-}\right)$o que atrai íons $\mathrm{Ca}^{2+}$ positivos, do fluido formando assim titanato de cálcio $\left(\mathrm{CaTiO}_{3}\right)$ amorfo. Simultaneamente, há o acúmulo de íons $\mathrm{Ca}^{2+}$, tornando a superfície levemente positiva, o que atrai íons fosfato $\left(\mathrm{PO}_{4}^{-2}\right)$, negativos, para formar o fosfato de cálcio $\left(\mathrm{Ca}_{3}\left(\mathrm{PO}_{4}\right)_{2}\right)$ amorfo. Esta camada é então cristalinizada, muitos núcleos de apatita são formados na superfície e crescem espontaneamente a partir do consumo de íons cálcio e íons de fosfato do SBF. A camada de apatita resultante é fortemente ligada ao substrato já que se integra ao titânio a partir do óxido de titânio (KOKUBO et al., 2006) (Figura 2.4). 

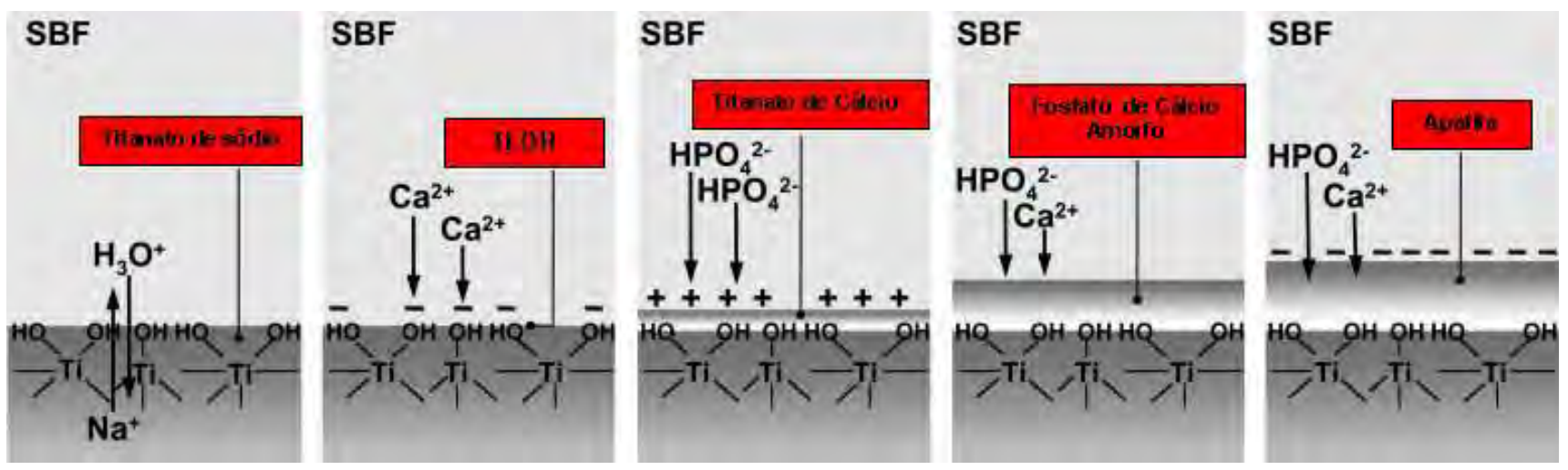

Figura 2.4 - Representação esquemática do mecanismo de formação de apatita em Ti imerso SBF (Adaptado de KOKUBO et al., 2006)

A deposição biomimética de fosfatos de cálcio foi realizada sobre diferentes tipos de substratos como biovidro, sílica gel, titânio, tântalo, membranas de politetrafluoretileno e polietilenotereftalato (JIANG et al., 2005). Quando o método biomimético é utilizado para revestir implantes metálicos, um dos pontos críticos é a questão do tempo, que é considerado relativamente grande para recobrir todo o substrato. Em função dessa problemática, vários trabalhos têm sugerido alguns tratamentos com o objetivo de diminuir o tempo de formação da apatita, como por exemplo, imergir os substratos em soluções cujas concentrações são maiores que as dos fluidos corpóreos (BARRERE et al., 2002).

Habibovic et al., (2002) avaliaram o uso de dois tipos de soluções de SBF (SBFA e SBF-B) excluindo os íons $\mathrm{K}^{+}$e $\mathrm{SO}_{4}{ }^{2-}$ (Quadro 2.6), baseadas no SBF original proposto por Kokubo et al., (1998). A solução SBF-A apresentava uma concentração 5x superior ao SBF convencional. A solução SBF-B apresentava a mesma composição do SBF-A, porém com com teores de $\mathrm{Mg}^{2+}$ e $\left(\mathrm{HCO}_{3}\right)^{-}$reduzidos. Os autores concluíram que para o crescimento de uma camada uniforme de apatita é necessário um prétratamento térmico antes da imersão em SBF e que as amostras imersas em solução com concentração $5 \mathrm{x}$ superior a solução convencional foram as que apresentaram maior crescimento de fosfato de cálcio. 
Quadro 2.6 - Composição inorgânica do Plasma humano, fluido corpóreo simulado (SBF) e soluções para revestimentos SBF-A e SBF-B (HABIBOVIC et a.l, 2002)

\begin{tabular}{|c|c|c|c|c|c|c|c|c|}
\hline \multirow{2}{*}{ Soluções } & \multicolumn{7}{|c|}{ Concentração iônica (mM) } \\
\cline { 2 - 10 } & $\mathbf{N a}^{+}$ & $\mathbf{K}^{+}$ & $\mathbf{C a}^{2+}$ & $\mathbf{M g}^{2+}$ & $\mathbf{C l}^{-}$ & $\mathbf{H P O}_{4}{ }^{2-}$ & $\mathbf{H C O}_{3}{ }^{-}$ & $\mathbf{S O}_{4}{ }^{2-}$ \\
\hline Plasma humano & 142 & 5 & 2,5 & 1,5 & 103 & 1 & 27 & 0,5 \\
\hline SBF & 142 & 5 & 2,5 & 1,5 & 148,8 & 1 & 4,2 & 0,5 \\
\hline SBF-A & 714,8 & - & 12,5 & 7,5 & 732,8 & 5 & 21 & - \\
\hline SBF-B & 704,2 & & 12,5 & 1,5 & 711,8 & 5 & 10,5 & - \\
\hline
\end{tabular}

Barrere et al., (2002) estudaram várias composições de soluções corpóreas simuladas com o propósito de avaliar a influência dos íons $\mathrm{HCO}_{3}{ }^{-}$e $\mathrm{NaCl}^{-}$ (Quadro 2.7), no processo de mineralização dos fosfatos de cálcio e observaram que a camada de apatita formada sobre a superfície do Ti-6Al-4V variou de acordo com a solução utilizada.

Quadro 2.7 - Composição de soluções corpórea simulada (Barrére et al., 2002)

\begin{tabular}{|c|c|}
\hline Soluções & Variação dos íons $\mathrm{HCO}_{3}{ }^{-} \mathbf{e ~ N a C l}^{-}$ \\
\hline SBF 5x & - \\
\hline SBF 5x $\left(\mathrm{HCO}_{3}^{-} \times \mathbf{0}\right)$ & Isento de $\mathrm{HCO}_{3}^{-}$ \\
\hline SBF 5x $\left(\mathrm{HCO}_{3}^{-} \times 3\right)$ & Concentração de $\mathrm{HCO}_{3}^{-} 3 \mathrm{x}$ \\
\hline SBF 5x $\left(\mathrm{NaCl}^{-} \times \mathbf{0}\right)$ & Isento de $\mathrm{NaCl}^{-}$ \\
\hline SBF 5x $\left(\mathrm{NaCl}^{-} \times 3\right)$ & Concentração de $\mathrm{NaCl}^{-} 3 \mathrm{x}$ \\
\hline
\end{tabular}

Para as soluções SBF 5x, SBF 5x $\left(\mathrm{HCO}_{3}^{-}\right.$x 0), SBF 5x $\left(\mathrm{HCO}_{3}^{-}\right.$x 3) e SBF $5 x\left(\mathrm{NaCl}^{-}\right.$x 3), o revestimento com Ca-P ocorreu em simultâneo com a precipitação. A camada de fosfato de cálcio apresentou-se densa e com cristais alongados. Tal como os precipitados, a deposição do revestimento foi dependente da composição da solução 
saturada. Já para a solução SBF 5x $\left(\mathrm{NaCl}^{-}\right.$x 0$)$, devido a uma baixa força iônica, o revestimento com Ca-P no substrato Ti-6Al-4V ocorreu no prazo máximo de precipitação da solução. Este início súbito de precipitação diminuiu acentuadamente a saturação da solução, e menos espécies iônicas ficaram disponíveis na solução para a nucleação Ca-P sobre Ti-6Al-4V. A camada de fosfato de cálcio apresentou constituída por cristais menores, e o substrato não foi totalmente revestido.

Wei et al., (2002) avaliaram muitos parâmetros de tratamento alcalino com tratamento térmico e imersão em solução $\mathrm{SBF}$, para tornar mais rápida a formação de apatita na liga Ti-6Al-4V. As amostras foram tratadas em soluções de $\mathrm{NaOH}$ ( 3, 5, 10 e $15 \mathrm{M}$ ) em temperaturas de 60 ou $80^{\circ} \mathrm{C}$; por 1,3 ou 7 dias. Verificou-se que o melhor tratamento para a liga Ti-6Al-4V foi em solução de $\mathrm{NaOH} 5 \mathrm{M}$ a $80^{\circ} \mathrm{C}$ por 3 dias. As amostras tratadas nestas condições foram posteriormente submetidas a tratamento térmico a 500, 600 e $700^{\circ} \mathrm{C}$ por 1 hora, a fim de consolidar a camada de hidrogel de titanato de sódio e melhorar sua adesão ao substrato. O tratamento térmico realizado a $600^{\circ} \mathrm{C}$ por 1 hora resultou na melhor adesão e melhor taxa de formação de apatita. Após a imersão em SBF, a formação de apatita sobre a liga Ti-6Al-4V ocorreu em apenas 3 dias, período bem mais curto que os 7 dias relatado por Kim et al. (1996).

Lee et al., (2002) analisaram amostras da liga $\mathrm{Ti}-6 \mathrm{Al}-4 \mathrm{~V}$ tratadas em $\mathrm{NaOH}$ a $5 \mathrm{M}$ por $24 \mathrm{~h}$, seguido por tratamento térmico a $600^{\circ} \mathrm{C}$ e $800^{\circ} \mathrm{C}$ por $1 \mathrm{~h}$ e imersão em $\mathrm{SBF}$. Os autores verificaram que em ambas as superfícies ocorreram a formação de uma camada porosa de titanato de sódio, porém após os tratamentos térmicos diferenças significativas foram encontradas. $\mathrm{O}$ aquecimento a $600^{\circ} \mathrm{C}$ proporcionou a formação de um filme de titanato de sódio cristalino, o que favoreceu o crescimento de apatita, enquanto o aquecimento a $800^{\circ} \mathrm{C}$ o crescimento de apatita foi bem menor.

Uchida et al., (2003) demonstraram que a habilidade de formação de apatita em titanato é dependente da estrutura cristalina do titanato. Gel de titanato com estrutura amorfa não induz a formação de apatita em sua superfície após imersão em SBF, enquanto géis com estrutura cristalina ( rutilo ou anatásio) induzem a formação de apatita em sua superfície. Além disso, deposição de apatita é mais pronunciada em gel de anatásio que em gel de rutilo. 
Miyazaki et al., (2000) estudaram amostras de tântalo tratadas com $\mathrm{NaOH}$ com concentrações variando de 0,2 a 5,0 M, e mantidas a $60^{\circ} \mathrm{C}$ por $24 \mathrm{~h}$. Após o período determinado, as amostras foram lavados com água destilada e secas a $40^{\circ} \mathrm{C}$ por $24 \mathrm{~h}$. Após o tratamento químico com soluções de 0,2 e 0,5 M NaOH uma camada amorfa de tantalato de sódio com $1 \mathrm{~mm}$ de espessura foi detectada, enquanto após o tratamento com $\mathrm{NaOH}$ a 5,0M, ocorreu a formação de uma camada cristalina de tantalato de sódio.

Essas camadas de tantalato de sódio são formadas quando a camada passiva de óxido de tântalo reage com a solução aquosa de $\mathrm{NaOH}$, conforme a reação:

$$
\mathrm{Ta}_{2} \mathrm{O}_{5}+\mathrm{OH}^{-} \rightarrow \mathrm{HTa}_{2} \mathrm{O}_{6}^{-}
$$

Em seguida, o substrato do metal tântalo reage a solução aquosa de $\mathrm{NaOH}$ :

$$
\begin{aligned}
& \mathrm{Ta}+2 \mathrm{OH}^{-} \rightarrow \mathrm{Ta}(\mathrm{OH})_{2}{ }^{3+}+5 \mathrm{e}^{-} \\
& \mathrm{Ta}+3 \mathrm{OH}^{-} \rightarrow \mathrm{Ta}(\mathrm{OH})_{3}{ }^{2+}+5 \mathrm{e}^{-} \\
& 2 \mathrm{Ta}(\mathrm{OH})_{3}{ }^{2+}+4 \mathrm{e}^{-} \rightarrow \mathrm{Ta}_{2} \mathrm{O}_{5} \cdot \mathrm{H}_{2} \mathrm{O}+2 \mathrm{H}_{2}^{-} \\
& \mathrm{Ta}(\mathrm{OH})_{2}{ }^{3+}+3 \mathrm{OH}^{-} \rightarrow \mathrm{Ta}(\mathrm{OH})_{5} \\
& \mathrm{Ta}_{2} \mathrm{O}_{5} \cdot \mathrm{H}_{2} \mathrm{O}+\mathrm{OH}^{-} \leftrightarrow \mathrm{HTa}_{2} \mathrm{O}_{6}^{-} \cdot \mathrm{H}_{2} \mathrm{O}
\end{aligned}
$$

O tantalato hidratado negativamente carregado é formado pela incorporação dos íons $\mathrm{Na}^{+}$. Como resultado, em baixas concentrações de $\mathrm{NaOH}$ ocorre a formação de uma camada de tantalato de sódio amorfo, e em elevadas concentrações de $\mathrm{NaOH}$ forma-se uma camada de tantalato de sódio cristalino. Como o tântalo é normalmente coberto por uma fina passiva camada de óxido de tântalo, a camada de óxido no metal pode ser hidratada em SBF formar grupos de Ta-OH. Esses grupos induzem a 
nucleação da apatita, que uma vez formados crescem consumindo íons cálcio e fósforo.

Miyazaki et al., (2001) analisaram amostras de tântalo previamente embebida em $\mathrm{NaOH} 0,5 \mathrm{M}$ a $60^{\circ} \mathrm{C}$ por $24 \mathrm{~h}$, e tratado termicamente a $300^{\circ} \mathrm{C}$ por $1 \mathrm{~h}$ para formar uma camada amorfa tantalato de sódio em sua superfície. Após a imersão em SBF por um período de 7 dias observaram uma camada de apatita semelhante ao osso formada em sua superfície. Essa rápida formação de apatita sobre a superfície do tântalo ocorreu devido a formação de tantalato de sódio cristalino sobre a superfície, possibilitando maior nucleação e crescimento da apatita.

\subsubsection{Apatita}

Dentre as diversas biocerâmicas estudadas destaca-se o fosfato de cálcio por apresentar ausência de toxicidade e de respostas inflamatórias quando inseridos no corpo humano e também habilidade em se ligar ao tecido ósseo (osseointegração). Tais características podem ser explicadas pela natureza química desses materiais, formados basicamente por íons de cálcio e fósforo, que além de participarem do equilíbrio iônico entre o fluido biológico e a cerâmica, possuem componentes inorgânicos semelhantes aos dos ossos e dentes (KAWACHI et al., 2000).

As apatitas biológicas, que compõem as fases minerais dos tecidos calcificados (esmalte, dentina e ossos) e algumas calcificações patológicas (cálculo dentário humano, cálculos salivar e urinário) são geralmente referidas como apatitas. O quadro 2.8 mostra as principais ocorrências de fosfatos de cálcio em sistemas biológicos (KAWACHI et al., 2000). 
Quadro 2.8 - Ocorrências de fosfatos de cálcio em sistemas biológicos (KAWACHI et al., 2000).

\begin{tabular}{|c|c|}
\hline FOSFATO DE CÁLCIO & OCORRÊNCIAS \\
\hline Hidroxiapatita (HA) & $\begin{array}{c}\text { Esmalte, dentina, osso, cálculo dentário } \\
\text { e urinário, pedras, calcificação de tecido } \\
\text { Fosfato de Cálcio Amorfo (ACP) }\end{array}$ \\
\hline Fosfato octacálcico (OCP) & Cálculo dentário e urinário \\
\hline Posfato tricálcico (TCP) & Cálculo dentário e urinário \\
\hline Monohidrogênio fosfato de cálcio & Cálculo dentário, ossos decompostos cáries dentárias. Calcificação \\
\hline dihidratado (DCPD) & \\
\hline
\end{tabular}

A classificação dos vários fosfatos de cálcio é realizada, utilizando-se a razão molar Ca/P (Quadro 2.9). Vários fosfatos de cálcio, que possuem razão entre 0.5 a 2.0, podem ser sintetizados por precipitação a partir de soluções contendo íons cálcio e fosfato, sob condições alcalinas ou ácidas (VALLET-REGÍ et al., 2001) 
Quadro 2.9 - Relação Ca/P das fases de apatita (VALLET-REGÍ et al., 2001)

\begin{tabular}{|c|c|c|c|}
\hline $\mathbf{C a} / \mathbf{P}$ & Fórmula & Nome & Abreviação \\
\hline 2,00 & $\mathrm{Ca}_{4} \mathrm{O}\left(\mathrm{PO}_{4}\right)_{2}$ & Fosfato tetracálcico & TTCP \\
\hline 1,67 & $\mathrm{Ca}_{10}\left(\mathrm{PO}_{4}\right)_{6} \cdot(\mathrm{OH})_{2}$ & Hidroxiapatita & HA \\
\hline 1,67 & $\mathrm{Ca}_{10-\mathrm{X}} \mathrm{H}_{2 \mathrm{X}}\left(\mathrm{PO}_{4}\right)_{6} \cdot(\mathrm{OH})_{2}$ & Hidroxiapatita deficiente em cálcio & ACP \\
\hline 1,50 & $\mathrm{Ca}_{3}\left(\mathrm{PO}_{4}\right)_{2}$ & Fosfato tricálcico & TCP \\
\hline 1,33 & $\mathrm{Ca}_{8} \mathrm{H}_{2}\left(\mathrm{PO}_{4}\right)_{6} \cdot 5 \mathrm{H}_{2} \mathrm{O}$ & Fosfato octacálcico & OCP \\
\hline 1,00 & $\mathrm{CaHPO}_{4} \cdot 2 \mathrm{H}_{2} \mathrm{O}$ & Hidrogeno fosfato de cálcio dihidratado & DCPD \\
\hline 1,00 & $\mathrm{CaHPO}_{4}$ & Hidrogeno fosfato de cálcio & DCP \\
\hline 1,00 & $\mathrm{Ca}_{2} \mathrm{P}_{2} \mathrm{O}_{7}$ & Pirofosfato de cálcio & CPP \\
\hline 1,00 & $\mathrm{Ca}_{2} \mathrm{P}_{2} \mathrm{O}_{7} \cdot 2 \mathrm{H}_{2} \mathrm{O}$ & Pirofosfato de cálcio dihidratado & CPPD \\
\hline 0,70 & $\mathrm{Ca}_{7}\left(\mathrm{P}_{5} \mathrm{O}_{16}\right)_{2} \mathrm{O}_{2}$ & Fosfato heptacálcico & HCP \\
\hline 0,67 & $\mathrm{Ca}_{4} \mathrm{H}_{2} \mathrm{P}_{6} \mathrm{O}_{20}$ & Dihidrogeno fosfato tetracálcico & TDHP \\
\hline 0,50 & $\mathrm{Ca}_{2}\left(\mathrm{H}_{2} \mathrm{PO}_{4}\right)_{2} \cdot \mathrm{H}_{2} \mathrm{O}$ & Fosfato monocálcico monohidratado & MCPM \\
\hline 0,50 & $\mathrm{Ca}_{2}\left(\mathrm{PO}_{3}\right)_{2}$ & Metafosfato de cálcio & CMP \\
\hline
\end{tabular}

- Hidroxiapatita - HA

A hidroxiapatita representa a fase mineral dos ossos e dentes, é responsável por fornecer estabilidade estrutural ao corpo, protegendo órgãos vitais como pulmões e coração, funcionando como um depósito regulador de íons. Tal fase de apatita representa aproximadamente $5 \%$ do peso total de um indivíduo adulto.

Apresenta a fórmula química $\mathrm{Ca}_{5}\left(\mathrm{PO}_{4}\right)_{3} \mathrm{OH}$ e razão molar $\mathrm{Ca} / \mathrm{P}$ de 1,67 . Em 1926, observou-se a semelhança entre os padrões de difração de raios X da fase mineral dos ossos e da HA. A fase mineral dos ossos não possui uma composição bem definida, pois apresenta variações nas fases da vida, como nos estágios de maturação e envelhecimento dos tecidos duros. Sendo assim, a maior diferença entre a HA sintética e a apatita óssea está na cristalinidade. A presença de íons $\mathrm{Na}^{+}, \mathrm{Mg}^{2+}, \mathrm{CO}_{3}{ }^{2-}$ e citratos e, em menores quantidades, $\mathrm{K}^{+}, \mathrm{Cl}^{-}$e $\mathrm{F}^{-}$são semelhantes para ambas (KAWACHI et al., 2000). 
O fosfato de cálcio mais utilizado em implantes é a hidroxiapatita, pois é o material mais semelhante ao componente mineral dos ossos. Exibe propriedades como biocompatibilidade, bioatividade, osteocondutividade, porém, suas propriedades mecânicas são pobres. Basicamente, sua tenacidade à fratura é muito baixa, restringindo o seu campo de aplicação. No entanto, é excelente para revestimento de implantes ou preenchimento de defeitos ósseos de pequeno porte. Na aplicação em implantes pode resultar numa combinação de boas propriedades mecânicas das ligas com a excelente biocompatibilidade e bioatividade da hidroxiapatita((VALLET-REGI et al., 2001). .

Quando comparado com hidroxiapatita estequiométrica, as apatitas biológicas, osso, dentina, esmalte, exibem uma ampla gama de composição. Eles são, portanto, marcadas por fases não-estequiométricas, sempre deficientes em cálcio e com carbonato na sua estrutura, com baixa cristalinidade, grandes quantidades de defeitos de rede, devido ao seu pequeno tamanho de partícula, área superficial específica. Do ponto de vista de sua composição, as apatitas biológicas são sempre deficientes em cálcio e carbonatadas, sendo então hidroxiapatita carbonatada. Os cristais de apatita que formam os ossos naturais são menores do que $500 \AA$ de tamanho. Este é um fator crucial para compreender a solubilidade das apatitas biológicas e a contínua regeneração óssea devido à dissolução constante ciclos de cristalização (VALLETREGI et al., 2001).

A hidroxiapatita é muito usada em implantes dentários devido a muitas vantagens: rápida adaptação óssea, interação direta entre implante/osso sem a formação de tecido fibroso, íntima adesão implante/tecido, tempo de cicatrização reduzida. Estas vantagens proporcionam outros fatores que podem aumentar a estabilidade por um longo período dos implantes, fornecendo maior tolerância com as mudanças ósseas naturais do osso circundante (Aparecida et al., 2007).

A hidroxiapatita apresenta uma lenta biodegradação. Estudos efetuados por longos períodos de tempo têm mostrado que a HA começa a ser reabsorvida gradualmente após 4 a 5 anos de implantação. A reabsorção é uma característica desejada para biomateriais nos quais o processo de degradação é concomitante com a reposição do osso em formação (KAWACHI et al., 2000). 
As biocerâmicas de fosfato de cálcio degradam com uma velocidade dada pela ordem: $\mathrm{CaHPO}_{4} \cdot 2 \mathrm{H}_{2} \mathrm{O}>\mathrm{CaHPO}_{4}>\mathrm{Ca}_{8} \mathrm{H}_{2}\left(\mathrm{PO}_{4}\right)_{6} \cdot 5 \mathrm{H}_{2} \mathrm{O}>\mathrm{Ca}_{3}\left(\mathrm{PO}_{4}\right)_{2}>$ $\mathrm{Ca}_{10}\left(\mathrm{PO}_{4}\right)_{6}(\mathrm{OH})_{2}$. A reabsorção do material, que representa esta degradação, é causada pela dissolução, que depende do produto de solubilidade do material e do pH local no meio fisiológico, pela desintegração física em partículas menores e, por fatores biológicos como fagocitose e a presença de leucócitos e de mediadores químicos que causam a redução do pH local (KAWACHI et al.,2000).

- Fosfato de Cálcio Amorfo - ACP

Fosfatos de cálcio quando são precipitados a partir de soluções aquosas supersaturadas, com $\mathrm{pH}$ neutro ou alcalino, forma-se rapidamente uma fase amorfa metaestável (KIM et al., 2005 ). Esta fase é denominada fosfato de cálcio amorfo ACP a qual corresponde a hidroxiapatita deficiente em cálcio - HAD. Forma partículas esféricas de 30 a 100nm, que são aglomerados de pequenas partículas (APARECIDA et al., 2007).

Baseado no método de difração de Rx, o ACP é considerado ser composto por clusters de composição $\mathrm{Ca}_{9}\left(\mathrm{PO}_{4}\right)_{6}$ com diâmetro de $0,95 \mathrm{~nm}$, denominados clusters de Posner, com moléculas de água nos interstícios (KIM et al., 2005).

As morfologias características para estas fases são, grãos esféricos e flocular (APARECIDA et al., 2007).

A formação de ACP de uma solução aquosa envolve um período de indução, o qual é influenciado pela presença de íons $\mathrm{Mg}^{2+}, \mathrm{CO}_{3}{ }^{2-}, \mathrm{F}^{-}, \mathrm{P}_{2} \mathrm{O}_{7}{ }^{4-}$ e poliacrilatos (APARECIDA et al., 2007).

A conversão de ACP em HA é um processo de dissolução - nucleação (KIM et al., 2005). O mecanismo de conversão de ACP em HA depende do pH da solução. Em $\mathrm{pH}$ fisiológico $(7,4)$ a hidrólise do ACP ocorre em duas etapas. Na primeira etapa, ocorre uma diminuição da razão $\mathrm{Ca} / \mathrm{P}$ da fase sólida (menor que 1,5) associada ao aumento do $\mathrm{pH}$. O produto iônico nesta solução aproxima-se do produto iônico do OCP. Na segunda etapa, um aumento da razão $\mathrm{Ca} / \mathrm{P}$ da fase sólida é observado com 
consumo de íons $\mathrm{OH}^{-}$da solução. Este estágio tem sido interpretado como a hidrólise do OCP a HA (SOMRANI et al., 2005).

O ACP encontra-se presente em muitos sistemas biológicos e como parte da composição de recobrimentos obtidos por plasma-spray tem sido considerado o responsável pela otimização das propriedades mecânicas destes recobrimentos, especialmente a adesão a superfícies metálicas, e das propriedades biológicas. Seu aumento nesses recobrimentos melhora sua propriedade osteocondutiva, no entanto pode degradar o material, danificando sua integração biológica com o tecido vivo (SOMRANI et al., 2005 ; APARECIDA et al., 2007).

\section{- Fosfato Octacálcico - OCP}

$\mathrm{O}$ fosfato octacálcico apresenta a fórmula $\mathrm{Ca}_{8}\left(\mathrm{HPO}_{4}\right)_{2}\left(\mathrm{PO}_{4}\right)_{4} .5 \mathrm{H}_{2} \mathrm{O}$, com a quantidade de água variável. É uma fase intermediária na precipitação de HA sintética e na formação de apatitas biológicas, pois nucleia e cresce mais facilmente que HA.

Estudo do efeito da adição de cálcio na formação de OCP e conversão em HA, utilizando soluções de fosfato de cálcio com variadas razões $\mathrm{Ca} / \mathrm{P}$, todas com $\mathrm{pH}$ 7,4 e temperatura de $37^{\circ} \mathrm{C}$, mostrou que a razão $\mathrm{OCP} / \mathrm{HA}$ do produto formado diminuiu conforme a velocidade de adição de $\mathrm{Ca}^{2+}$ também diminuiu, e este comportamento tornou-se acentuado quando a razão $\mathrm{Ca} / \mathrm{P}$ da solução aumentou. A adição de cálcio numa velocidade apropriada foi crucial para manter o grau de supersaturação do OCP durante a reação e, desse modo, regulou a formação e transformação do OCP a HA. A estabilidade do OCP aumentou e a transformação a HA tornou-se baixa com o aumento na duração de adição de $\mathrm{Ca}^{2+}$ (SOMRANI et al., 2005).

- Fosfato Tricálcico - TCP

O fosfato tricálcico apresenta a fórmula $\mathrm{Ca}_{3}\left(\mathrm{PO}_{4}\right)_{2}$ com razão $\mathrm{Ca} / \mathrm{P}$ de 1,5 , e também pode ser denominado de fosfato tricálcico anidro, onde o adjetivo anidro é utilizado para distinguir este composto dos precipitados hidratados que possuem razão $\mathrm{Ca} / \mathrm{P}$ similar (KIM et al., 2005). 
Como as cerâmicas de TCP são classificadas como biodegradáveis tornaram-se objeto de interesse na área de biomaterias tanto quanto as cerâmicas de hidroxiapatita (KAWACHI et al., 2000).

A formação de apatitas na superfície de várias biocerâmicas quando imersas em SBF foi avaliada por Xin et al., (2005). Os resultados mostraram que a fase de apatita formada em todas as biocerâmicas foi identificada como sendo TCP na forma alotrópica $\alpha$, a qual foi responsável pela formação de hidroxiapatita na superfície da biocerâmica. 


\section{MATERIAIS E MÉTODOS}

A metodologia empregada para o desenvolvimento dessa pesquisa pode ser dividida basicamente em três etapas: obtenção das amostras (Figura. 3.1a), modificação (Figura. 3.1b) e caracterização da superfície (Figura.3.1c) conforme pode ser observado na figura 3.1.

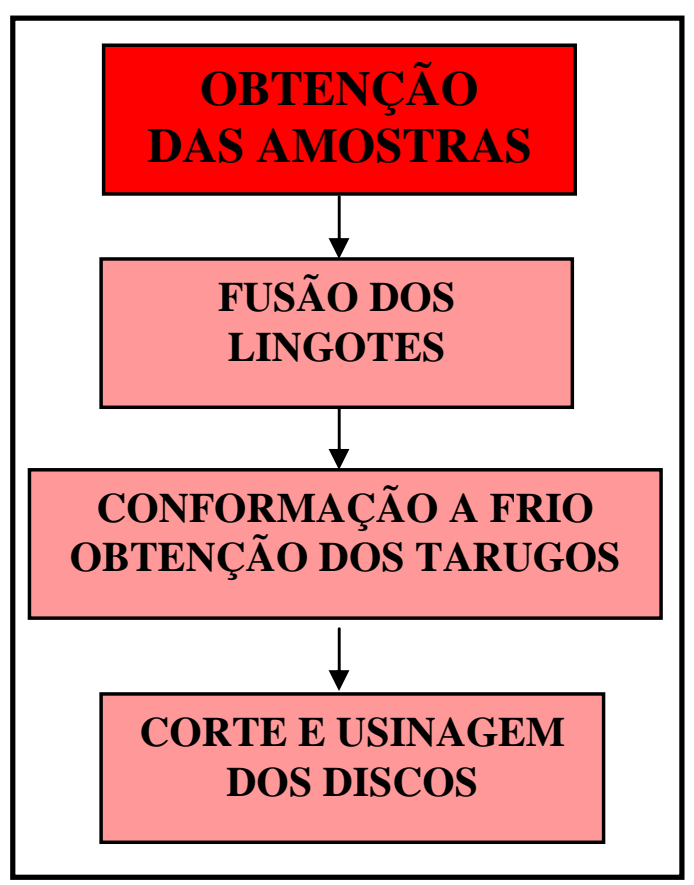

(a)

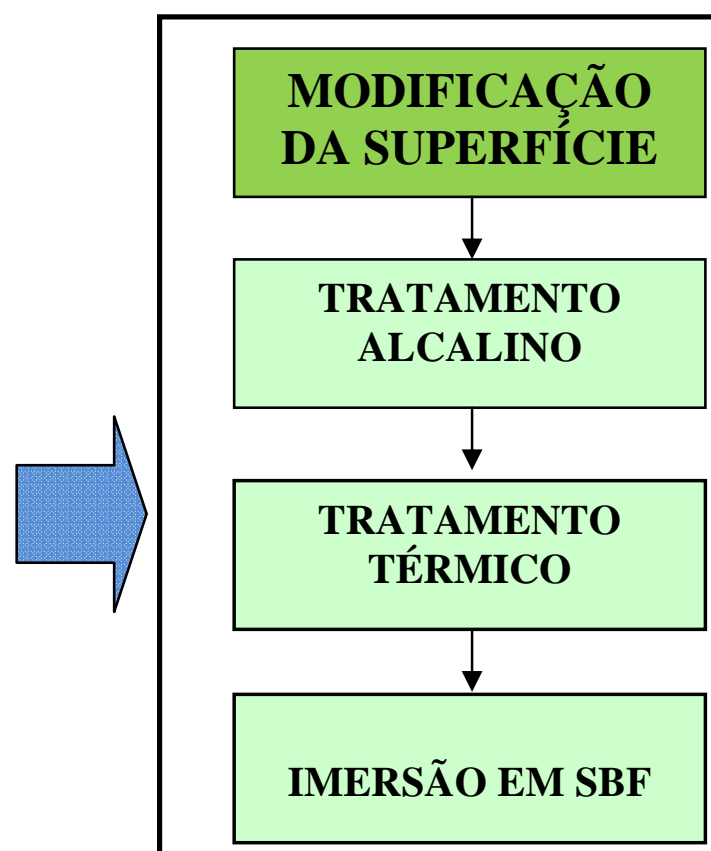

(b)

CARACTERIZAÇÃO DA SUPERFÍCIE

\begin{tabular}{|c|}
\hline MICROSCOPIA \\
DE FORÇA \\
ATÔMICA \\
(AFM)
\end{tabular}

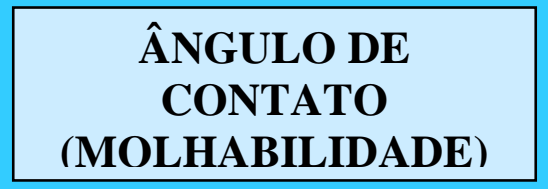

\begin{tabular}{|c|}
\hline MICROSCOPIA \\
ELETRÔNICA DE \\
VARREDURA \\
(MEV)
\end{tabular}

\section{DIFRAÇÃO DE \\ RAIOS-X \\ (DRX)}

(c)

Figura 3.1 - Representação esquemática da metodologia empregada no desenvolvimento da pesquisa: (a) Obtenção das amostras; (b) Modificação da superfície; (c) caracterização da superfície 


\subsection{PROCESSAMENTO DAS LIGAS}

Inicialmente foram fundidos lingotes da liga Ti-30Ta\%p a partir dos elementos puros, de acordo com a sequiência preconizada por Alves (1998): limpeza dos materiais, pesagem e fusão.

A limpeza foi realizada empregando-se a decapagem química, a partir de uma solução preparada com reagentes de grau analítico (P.A. Merck) composta por $50 \mathrm{ml}$ de ácido sulfúrico $\left(\mathrm{H}_{2} \mathrm{SO}_{4}\right), 20 \mathrm{ml}$ de ácido fluorídrico $(\mathrm{HF}), 20 \mathrm{ml}$ de ácido nítrico $\left(\mathrm{HNO}_{3}\right)$ e $10 \mathrm{ml}$ de água destilada. A pesagem na composição escolhida para estudo (Ti-30Ta\%p) foi então realizada em uma balança analítica e a fusão dos elementos em um forno a arco voltaico com atmosfera controlada e cadinho de cobre refrigerado (Figura 3.2).

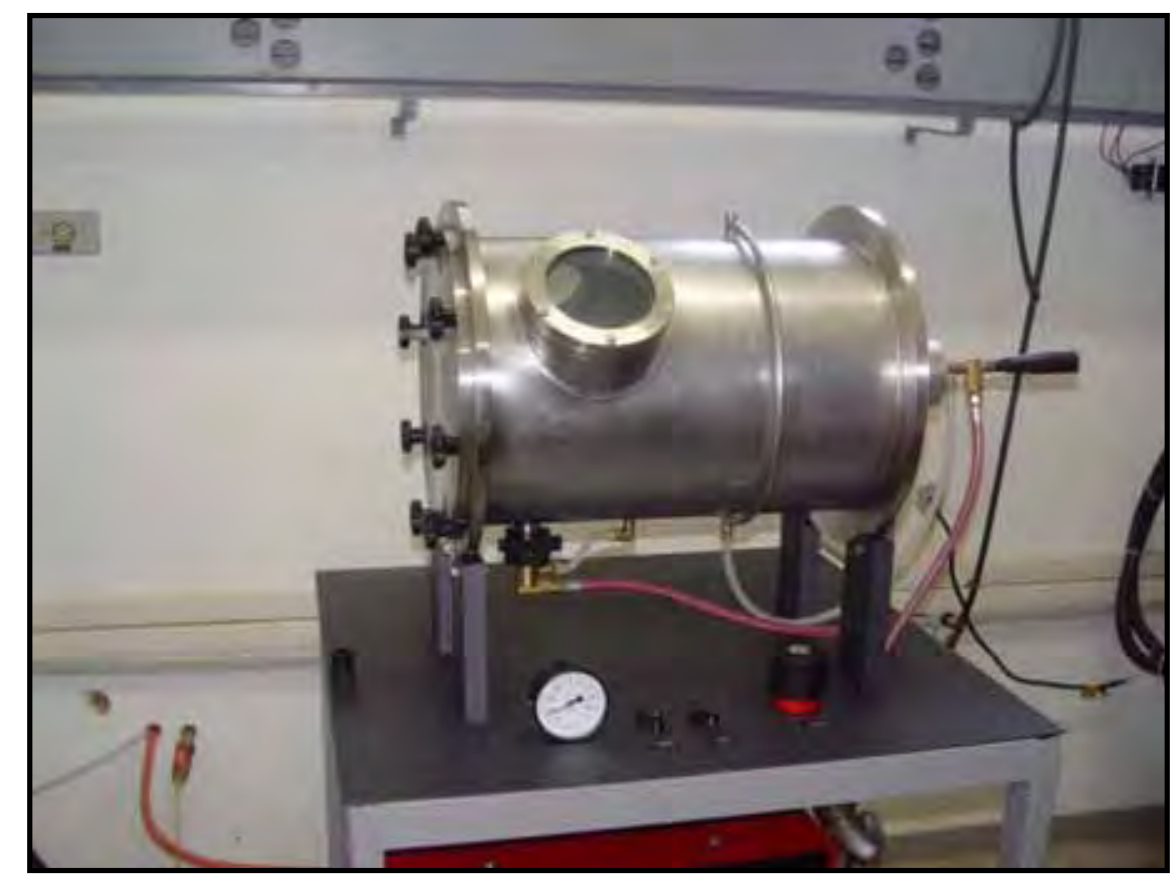

Figura 3.2 - Forno a arco voltaico empregado no preparo das ligas

Após a fusão, os lingotes foram encapsulados a vácuo, em tubo de quartzo, para o tratamento térmico. Esse tratamento foi realizado em forno tubular (Departamento de Engenharia de Materiais, Escola de Engenharia de Lorena, USP), com aquecimento a $1100{ }^{\circ} \mathrm{C}$ por 24 horas, seguido de resfriamento rápido em água gelada (Figura 3.3). 


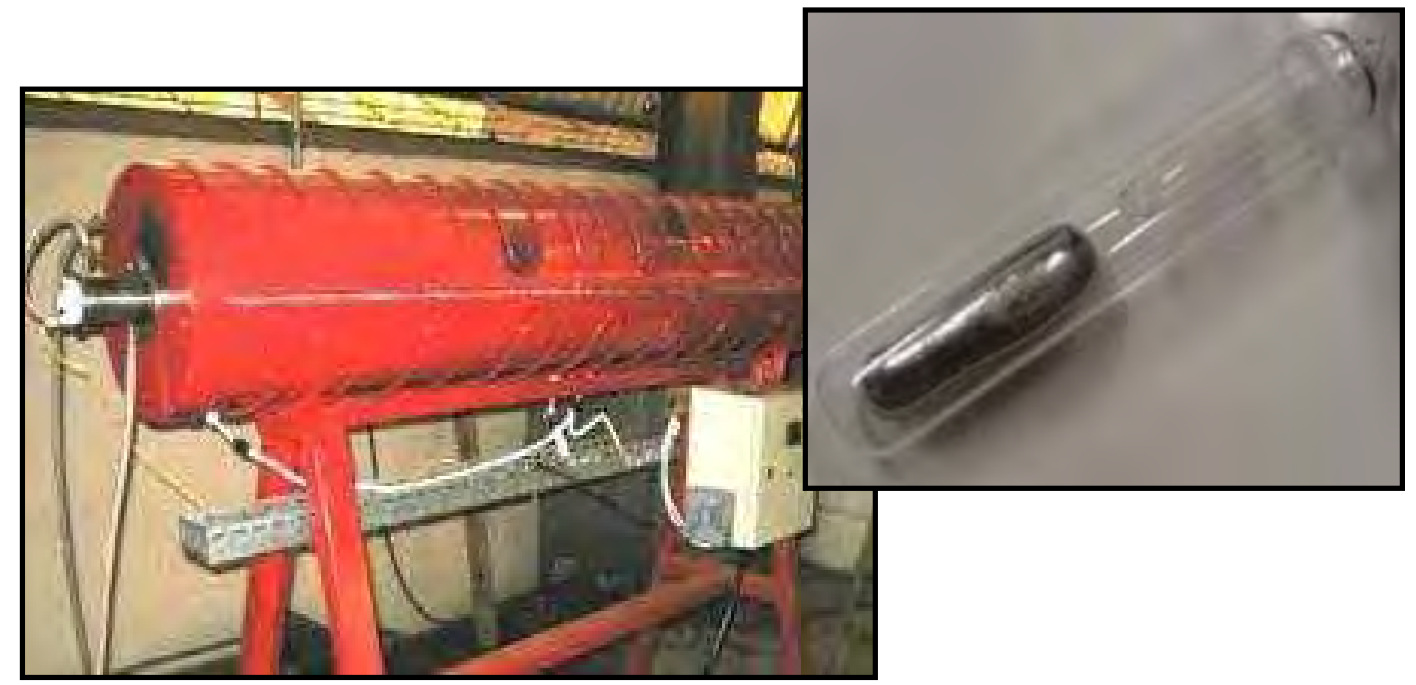

Figura 3.3 - Forno tubular empregado para homogeneização das ligas. Detalhe do lingote encapsulado a vácuo

Posteriormente ao tratamento térmico foi realizado o forjamento a frio dos lingotes de tal forma que tarugos com $13 \mathrm{~mm}$ fossem obtidos. O forjamento foi realizado em uma forja do tipo swaging (forjamento rotativo), FENN, utilizando matrizes $6 \mathrm{~F}\left(2^{2}\right.$ até $\left.3 / 8^{2}\right)$ e $3 \mathrm{~F}\left(1 / 2^{2}\right.$ até $\left.1 / 8^{2}\right)$, com potência de aproximadamente $30 \mathrm{CV}$ (HP) e velocidade de $1700 \mathrm{rpm}$, pertencente ao Departamento de Engenharia de Materiais, EEL, USP (Figura 3.4). A cada passe ocorreu a troca das matrizes (martelos), causando redução da ordem de $20 \%$ no diâmetro das amostras (diâmetro final de $13 \mathrm{~mm}$ ).

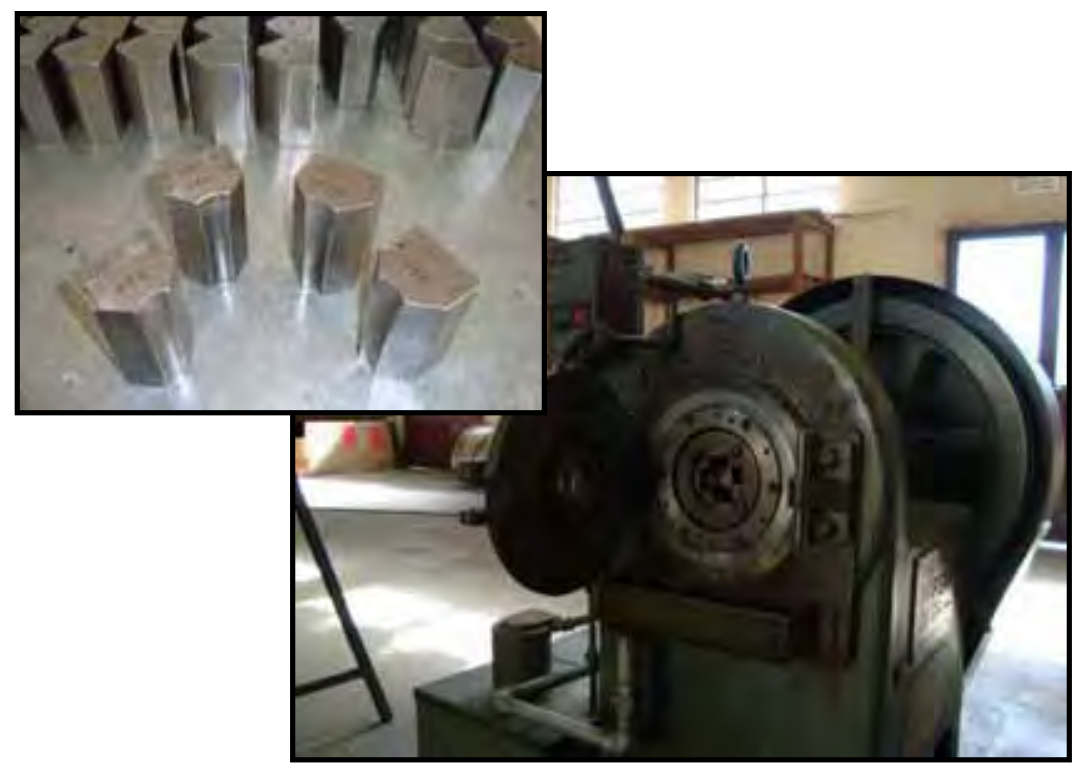

Figura 3.4 - Equipamento para forjamento à frio FENN e os martelos. 


\subsection{USINAGEM DOS DISCOS}

Após o forjamento a frio, os tarugos foram usinados, sendo faceada uma de suas faces de tal forma que uma rugosidade de aproximadamente 2,5 $\mu \mathrm{m}$ fosse obtida (Figura 3.5). Esse procedimento foi adotado buscando simular as condições encontradas na usinagem de implantes.

A rugosidade $\left(\mathrm{R}_{\mathrm{a}}\right)$ foi medida utilizando rugosímetro digital (Prazis Rug03, Mitutoyo, São Paulo) sendo tomados cinco valores em regiões distintas para o cálculo do $R_{a}$ médio. $O$ equipamento utilizado para a usinagem foi um torno CNC Centur 30 Romi, utilizando uma ferramenta UBMT 110404-UF 4225 (ISO $\mathrm{P} 25)$, com avanço de $0,2 \mathrm{~mm} /$ volta, profundidade de usinagem de $0,1 \mathrm{~mm}$ e velocidade de corte de $70 \mathrm{~m} / \mathrm{min}$.

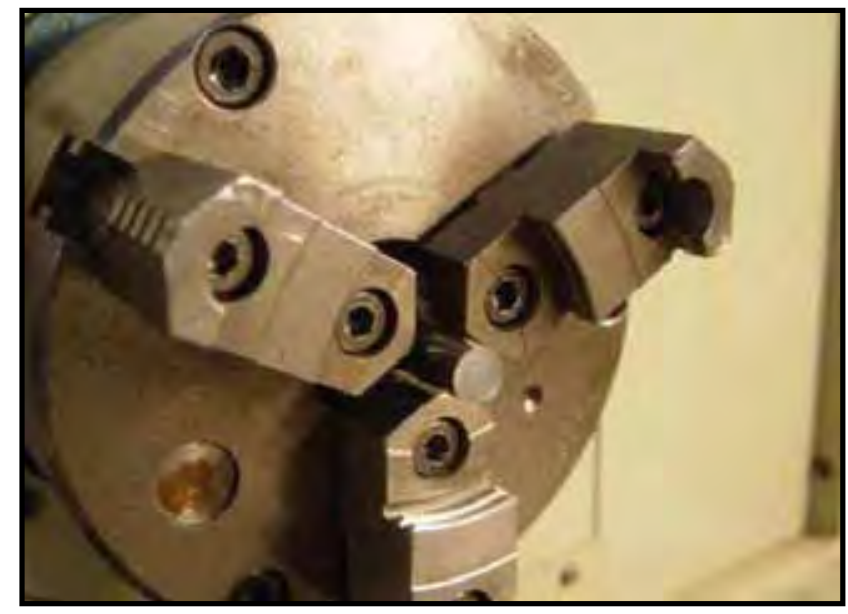

Figura 3.5 - Detalhe do tarugo preso a castanha do torno antes da usinagem

Após cada usinagem, o tarugo faceado foi levado a uma máquina de corte (Isomet 1000, Buehler) sendo seccionado um disco (3mm de espessura e $13 \mathrm{~mm}$ de diâmetro) contendo uma face usinada e outra lisa. Foram utilizadas dez amostras para cada condição. Posteriormente, as amostras foram lavadas em ultrassom com acetona (P.A. Merck) por 15 minutos . 


\subsection{MODIFICAÇÃO DA SUPERFÍCIE}

A modificação de superfície foi realizada em três etapas, empregando-se: tratamento alcalino, tratamento térmico e imersão em SBF.

\subsubsection{Tratamento Alcalino}

Para o tratamento alcalino, as amostras foram imersas em uma solução aquosa de $\mathrm{NaOH}$ a $0,5 \mathrm{M}$, em banho termostatizado (TE 184 , Tecnal) a $60^{\circ} \mathrm{C}$, por 24 horas conforme metodologia adotada por Miyazaki et al. (2002) para o tântalo C.P. (Figura 3.6). Após esse período foram lavadas abundantemente em água destilada e secas em estufa (Quimis) a $40^{\circ} \mathrm{C}$ por 24 horas.

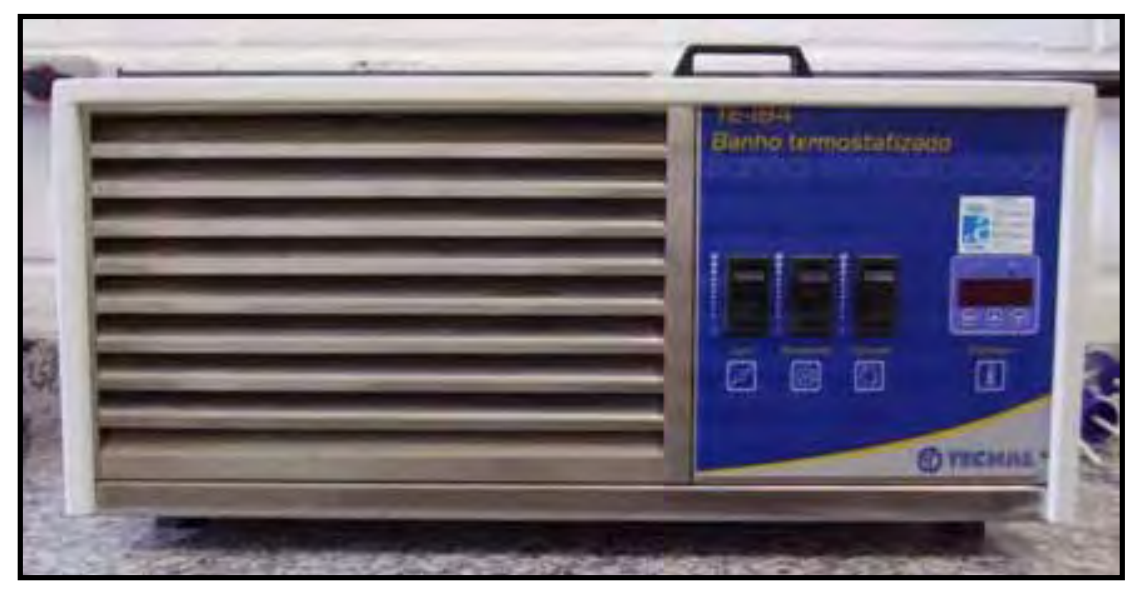

Figura 3.6 - Banho termostatizado (TE 184, Tecnal)

\subsubsection{Tratamento Térmico}

Após o tratamento alcalino, as amostras foram tratadas termicamente de acordo com a metodologia proposta por Myazaki et al., (1999) para o tântalo CP. Foi utilizado um forno EDG com aquecimento por resistência elétrica, a $300^{\circ} \mathrm{C}$ por 24 horas, com taxa de aquecimento de $5^{\circ} \mathrm{C} / \mathrm{min}$ (Figura 3.7). O resfriamento das amostras foi realizado dentro do forno até a temperatura ambiente. 


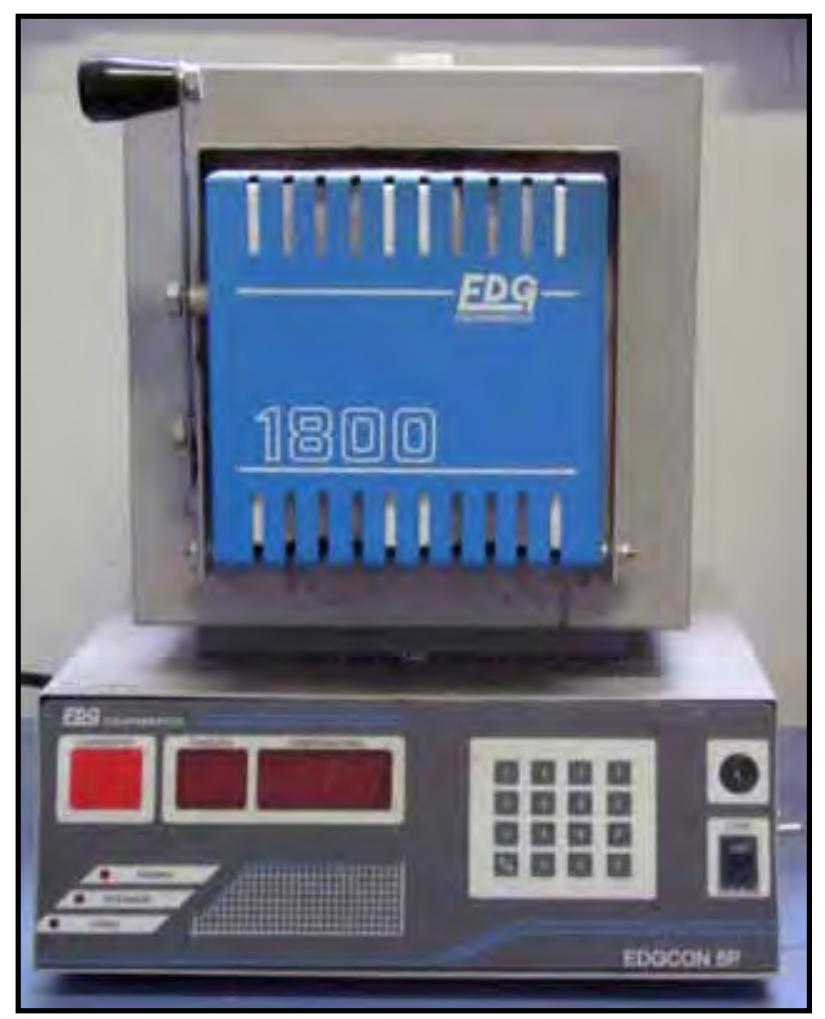

Figura 3.7 - Forno EDG com aquecimento por resistência elétrica

\subsubsection{Imersão em SBF}

A composição escolhida para a elaboração do SBF foi a proposta por Barrére et al., (2002), cuja concentração dos componentes é cinco vezes maior do que a solução original proposta por Kokubo (1998). No quadro 3.1 é possível verificar as composições empregadas.

Quadro 3.1 - Composição SBF 5x (Barrère et al., 2002)

\begin{tabular}{|c|c|}
\hline Componente & Quantidade (g/l) \\
\hline $\mathbf{N a C l}$ & 40,0 \\
\hline $\mathbf{M g C l}_{\mathbf{2}} \cdot \mathbf{6} \mathbf{H}_{\mathbf{2}} \mathbf{O}$ & 1,52 \\
\hline $\mathbf{C a C l}_{\mathbf{2}} \cdot \mathbf{2} \mathbf{H}_{2} \mathbf{O}$ & 1,84 \\
\hline $\mathbf{N a}_{2} \mathbf{H P O}_{\mathbf{4}} \cdot \mathbf{2} \mathbf{H}_{\mathbf{2}} \mathbf{O}$ & 0,89 \\
\hline $\mathbf{N a H C O}$ & 1,76 \\
\hline
\end{tabular}


Os reagentes foram dissolvidos em água destilada $(900 \mathrm{ml})$, mantida a $36,5^{\circ} \mathrm{C}$ com auxilio de uma mesa aquecedora, com agitação magnética. Duas metodologias foram empregadas para o ajuste do pH da solução: uso de TRIS (tris-hidroximetil-amino-metano) e gás carbônico $\left(\mathrm{CO}_{2}\right)$. Dessa forma as amostras foram divididas em dois grupos, I e II, de acordo com a técnica escolhida.

A adição do Tris (hidroximetil - aminometano) foi feita após a dissolução dos reagentes e até que a solução atingisse pH de 7,45, medido com auxílio de peagômetro (grupo I). A solução foi colocada em um balão volumétrico e seu volume completado com água destilada até $1000 \mathrm{ml}$.

Para a solução do grupo II, um fluxo constante de $\mathrm{CO}_{2}$ foi empregado durante a adição dos reagentes, sendo mantido por mais 20 minutos, até que a solução final ficasse translúcida, com pH em torno de 6,0 (Figura 3.8).

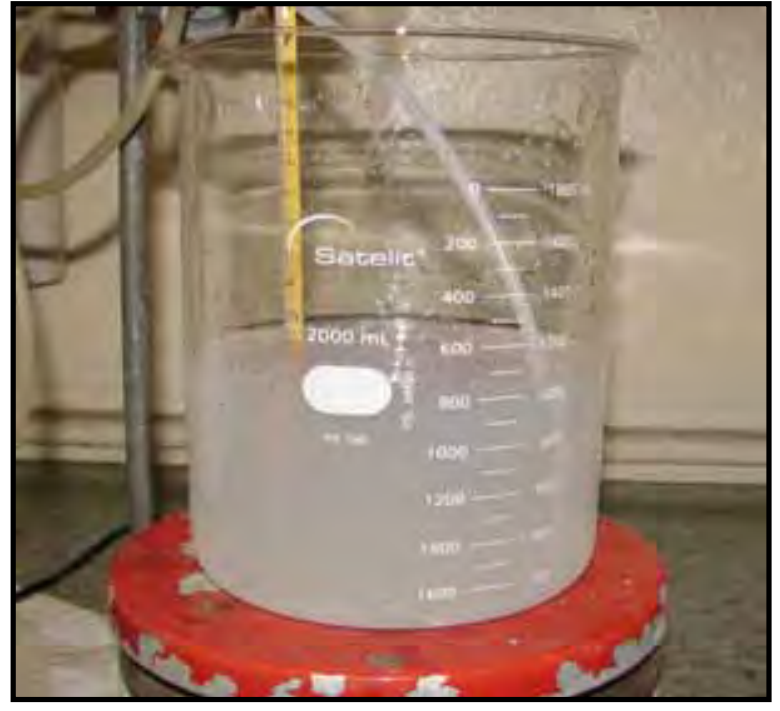

(a)

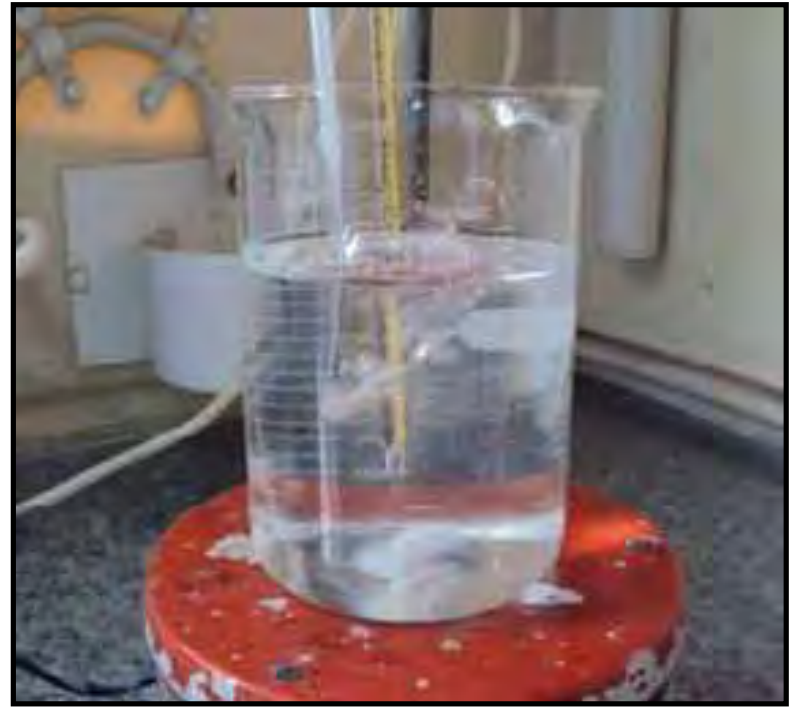

(b)

Figura 3.8 - Preparo do SBF com inserção de $\mathrm{CO}_{2}$ (a) inicio e (b) final do preparo

As amostras do grupo I foram imersas dentro de um funil para evitar deposição irregular de apatita conforme proposto por Kokubo, (1998) (Figura 3.9). Para esse grupo as amostras foram divididas em dois subgrupos, de acordo com o período de imersão, 7 e 14 dias. Em seguida, foram lavadas em água destilada e secas em estufa por 24 horas a $40^{\circ} \mathrm{C}$. 


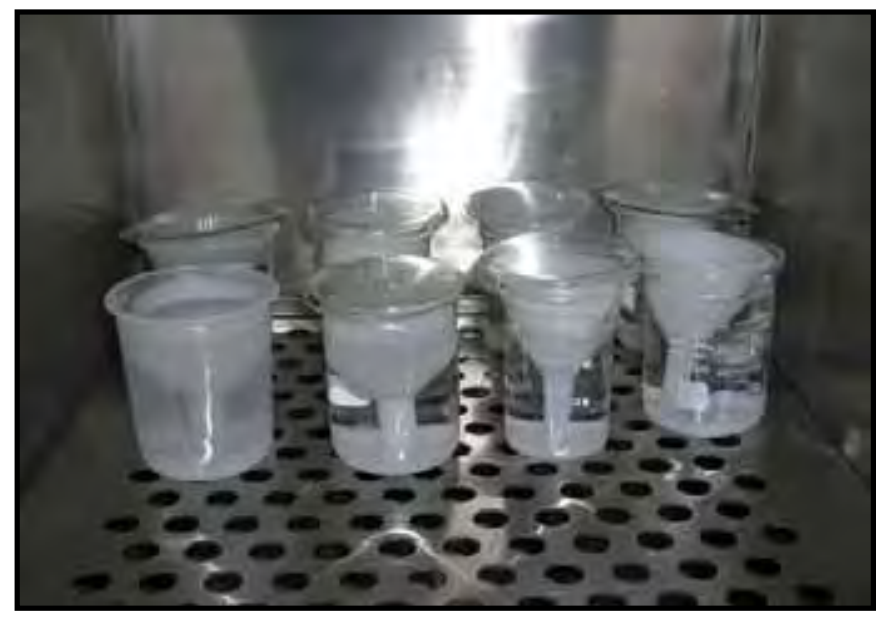

Figura 3.9 - Detalhe das amostras imersas em SBF utilizando funil para homogeneização do depósito da apatita

Para o grupo II, as amostras foram imersas em $30 \mathrm{ml} \mathrm{de} \mathrm{SBF,} \mathrm{de} \mathrm{acordo}$ com o grupo, em tubo Falcon, com a superfície usinada paralela ao fundo do tubo conforme representado na figura 3.10a. Os tubos foram colocados em uma mesa agitadora (Tecnal TC-420) a 36,5 ${ }^{\circ} \mathrm{C}$ com rotação de $175 \mathrm{rpm}$ durante 24 horas , pertencente ao Departamento de Biotecnologia, EEL, USP (Figura 3.10b). Após esse período as amostras foram retiradas, lavadas em ultrassom com água destilada por 10 minutos e secas em estufa a $50^{\circ} \mathrm{C}$ por 24 horas.

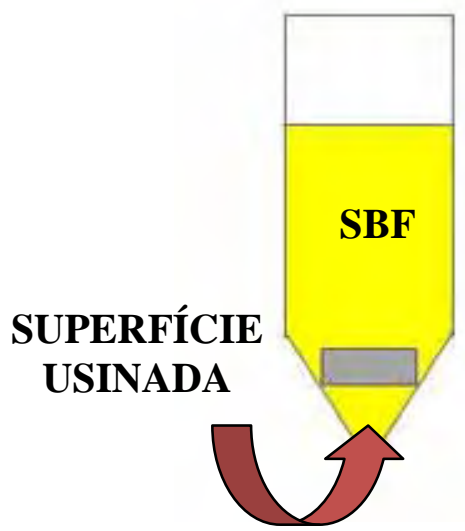

(a)

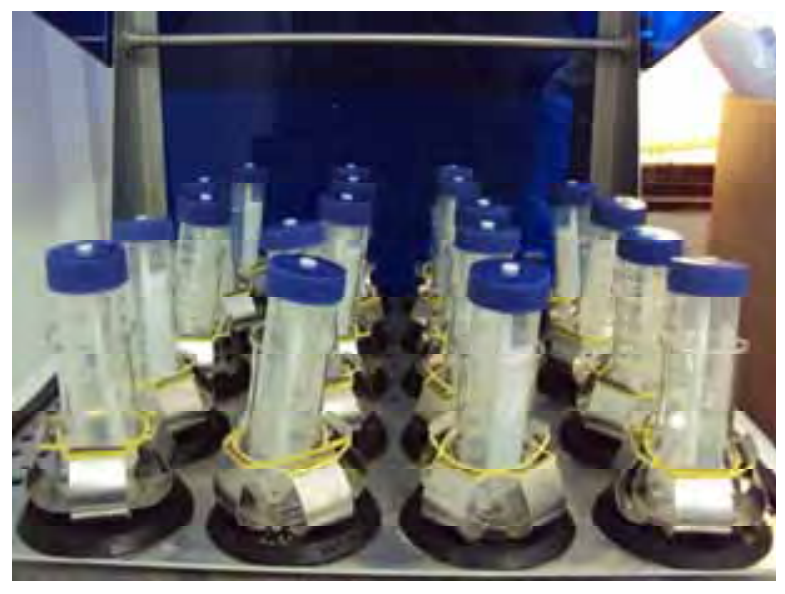

(b)

Figura 3.10 - (a) Representação esquemática da amostra no tubo Falcon; (b) montagem dos tubos em uma mesa agitadora 


\subsection{CARACTERIZAÇÃO DA SUPERFICIE}

\subsubsection{Microscopia Eletrônica de Varredura}

Para avaliação da superfície das amostras foi utilizado o microscópio eletrônico de varredura (MEV - Leo - 1450 VP), do Laboratório Associado de Sensores e Materiais - LAS , Instituto Nacional de Pesquisas Espaciais - INPE (Figura 3.11).

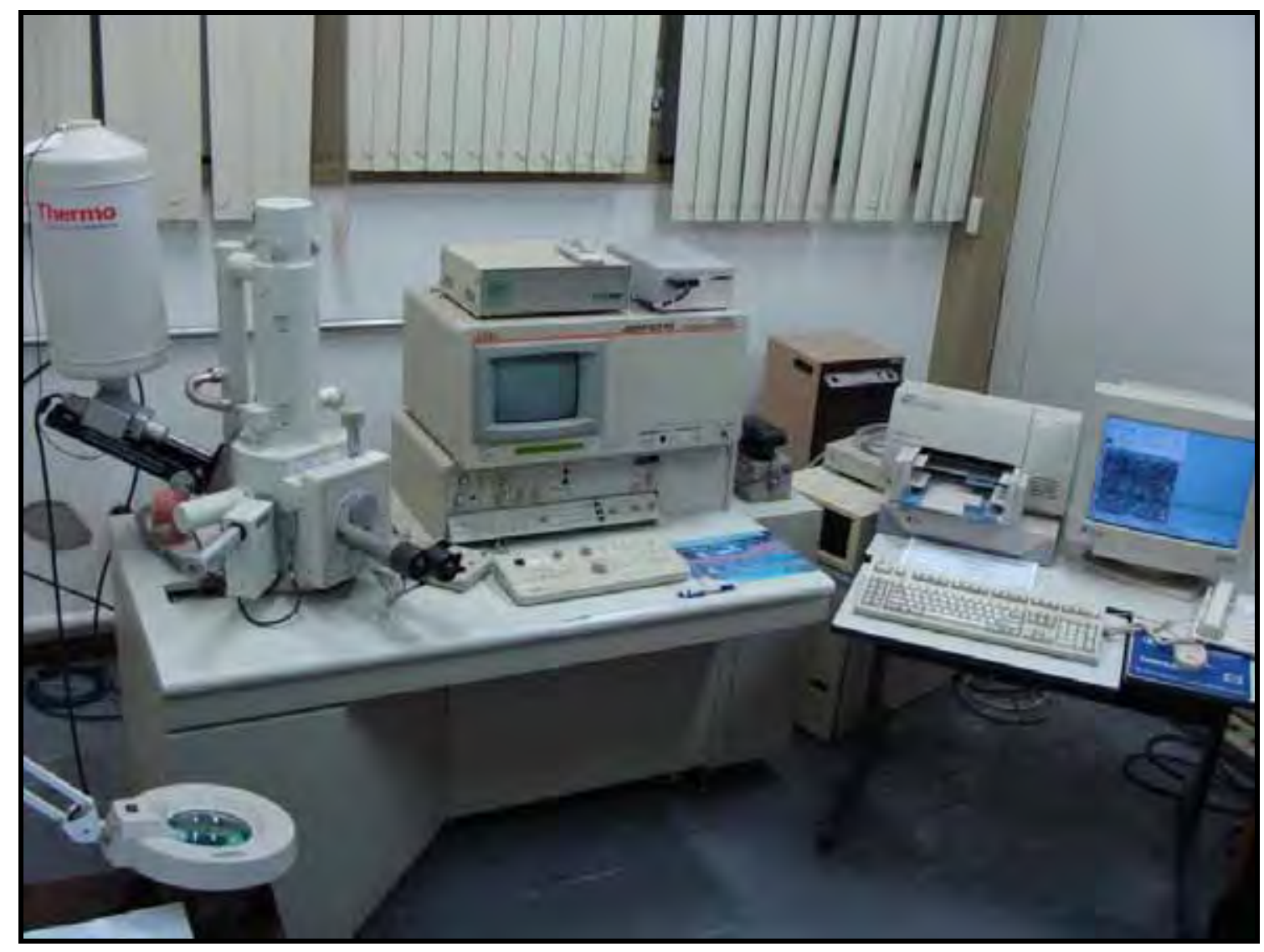

Figura 3.11 - Microscópio eletrônico de varredura empregado para análise da superfície

\subsection{2 Ângulo de Contato}

A molhabilidade é uma medida macroscópica que permite a determinação da energia de superfície de um determinado material. Para isso, uma gota de uma dada solução é pipetada sobre uma determinada amostra em estudo. Após a deposição da gota observa-se a forma da gota e a curvatura da mesma, ou seja, o 
ângulo de contato. Este é definido como o ângulo entre um plano tangente a uma gota do líquido e um plano contendo a superfície onde o líquido se encontra depositado.

Pela medida do ângulo da curvatura pode-se relacionar ângulo de contato com a tensão superficial apresentada pelo material em relação à solução empregada. $\mathrm{O}$ aumento no ângulo de contato, que corresponde à menor tensão superficial apresentada, significa menor aderência da solução aos materiais empregados. O conceito de energia de superfície pode ser mais facilmente compreendido usando um líquido como exemplo. Átomos e moléculas do líquido podem se mover livremente procurando ocupar uma posição de menor energia potencial. Ou seja, um lugar onde as forças (atrativas e repulsivas) agindo em todas as direções estejam em equilíbrio. Por outro lado, as partículas na superfície do material experimentam apenas forças dirigidas para dentro do líquido. Devido a isto, as superfícies são sempre regiões de maior energia. E é justamente a diferença entre as energias das amostras na superfície e no interior do material que se denomina energia de superfície ou tensão interfacial.

Estudos do ângulos de contato foram realizados no Laboratório Associado de Sensores e Materiais - LAS , Instituto Nacional de Pesquisas Espaciais - INPE, utilizando um Goniômetro automatizado (Ramé-Hard Instrument Co. - modelo-Advanced Goniometer model $\mathrm{n}^{\circ} 300-\mathrm{F} 1$, Serial $\mathrm{n}^{\circ}$ 709262) (Figura 3.12). O equipamento possui uma câmera, que captura a imagem da gota sendo depositada sobre a amostra, por meio de um dispositivo semelhante a um conta-gotas. O perfil desta gota é determinado por um programa de computador que calcula o ângulo de contato das superfícies. 


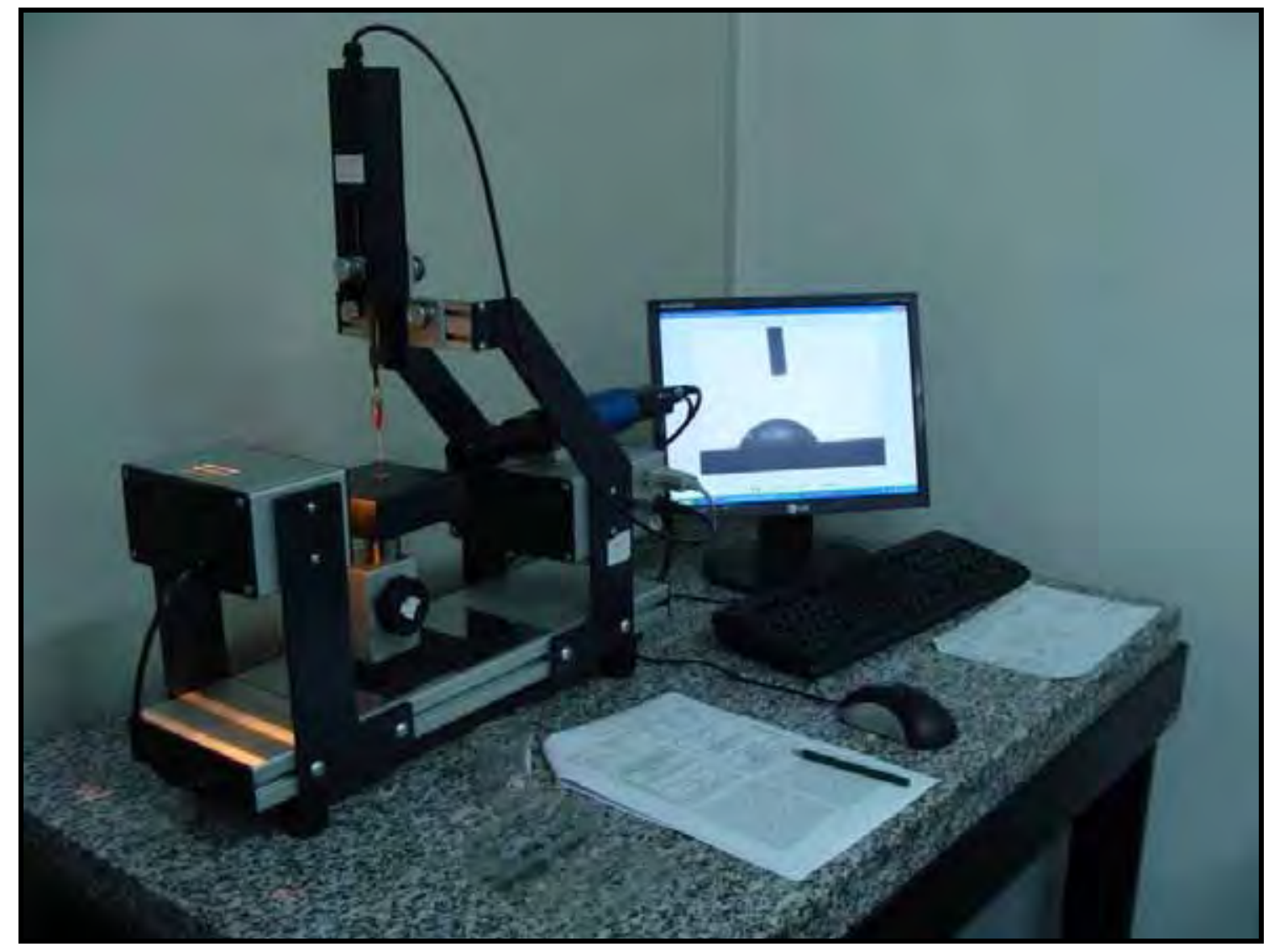

Figura 3.12 - Equipamento empregado para medida do ângulo de contato

\subsubsection{Microscopia de Força Atomica}

A análise de AFM foi realizada no Laboratório Associado de Sensores e Materiais - LAS , Instituto Nacional de Pesquisas Espaciais - INPE, utilizando um microscópio de força atômica V Nanoscope Veeco. Durante a análise, o microscópio foi operado no modo de contato sendo utilizado um cantilever Vshape Si3N4 (digitalização taxa de 0,5 Hz). Em tal modo operacional, o sistema de resposta do microscópio foi regulado para manter a distância entre a ponta do microscópio e as superfícies constante durante a varredura da amostra, e o movimento $\mathrm{z}$ realizado pelo piezoelétrico cerâmico foi registrado durante a digitalização.

Esta técnica de microscopia consiste em monitorar a força entre uma ponta de prova e a superfície da amostra. Existem várias forças de interação entre ponta-amostra. Dependendo do regime de forças envolvido, repulsiva ou atrativa, existem três modos de operação para a microscopia de força atômica. Num 
regime de força repulsivo a ponta e amostra estão em contato, por essa razão denominamos modo contato. Devido à delicadeza de amostras biológicas, esse modo de operação pode causar deformações e danos na superfície analisada, uma vez que a força e área envolvidas na medida são pequenas provocando uma grande pressão no local da medida. Assim, no modo não contato não existe um contato físico direto entre ponta e superfície preservando a qualidade dos resultados.

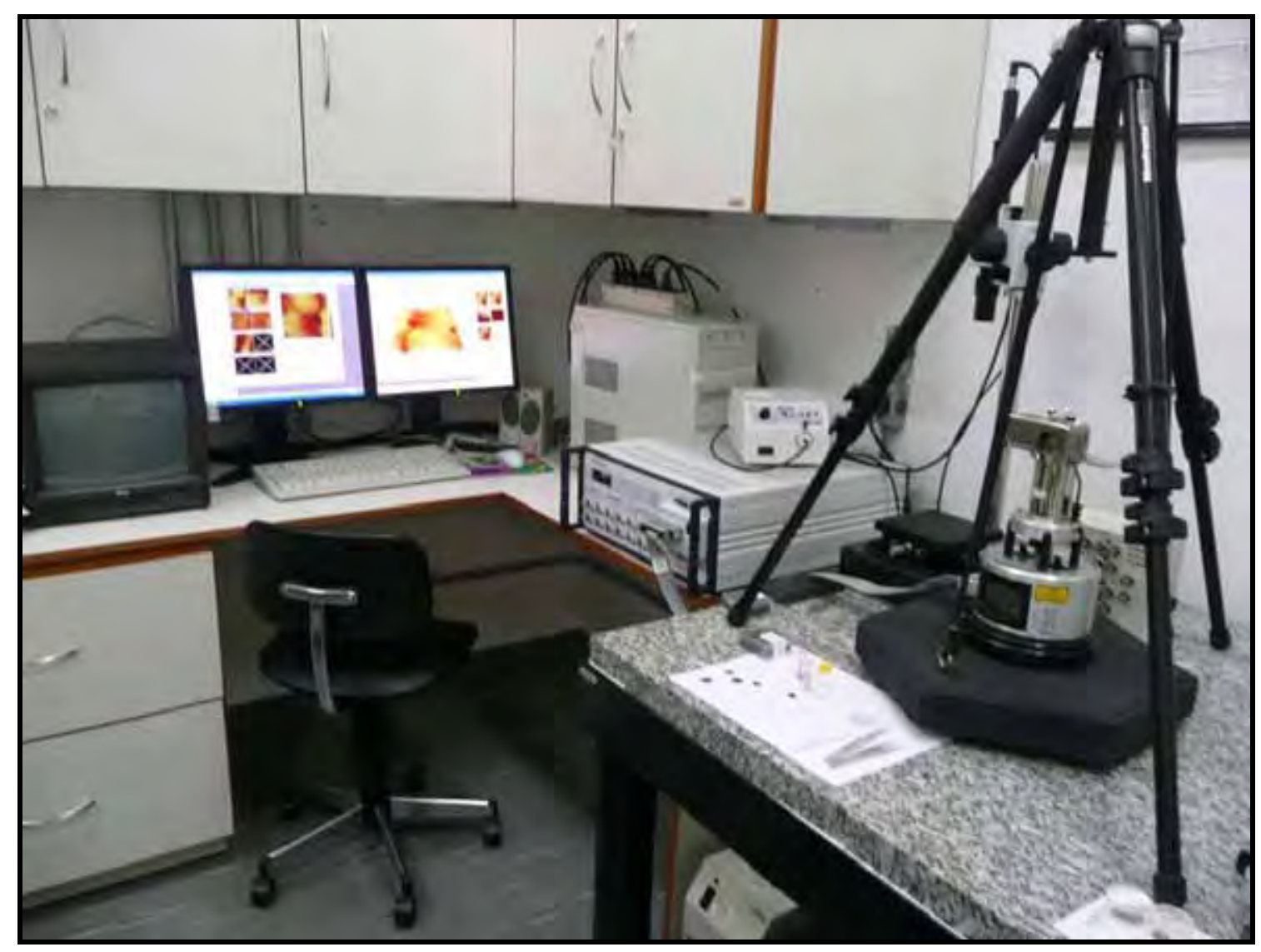

Figura 3.13- Microscópio de força atômica empregado para análise da superfície

\subsubsection{Difração de Raios $\mathbf{X}$}

Este método faz uso dos Raios X de comprimentos de onda conhecidos para determinar os espaçamentos dos planos cristalinos desconhecidos .Os Raios $\mathrm{X}$ são ondas eletromagnéticas de alta energia e pequeno comprimento de onda. Quando o feixe de Raios X atinge os átomos do material a ser analisado, seus elétrons são acelerados e passam a reemitir radiação com a mesma energia 
(mesmo comprimento de onda), porém em todas as direções. Se os átomos estiverem num arranjo periódico, as ondas sofrerão interferência, ou seja, ocorre uma reflexão apenas em certos ângulos de incidência e reflexão.

Para a identificação das fases presentes na liga Ti30Ta e das fases formadas após a reação da liga com $\mathrm{NaOH}$ e imersão em SBF foi utilizada a técnica de difratometria de raios com incidência rasante (equipamento Philips X’Pert PRO MPD PW3373/00). Esta técnica permite que o feixe de Raios X interaja com finas camadas de material que podem ser de alguns nanômetros a poucos micrometros. Neste caso é mantido constante o ângulo de incidência formado entre a fonte de Raios X e a superfície da amostra (ângulo Omega) e é

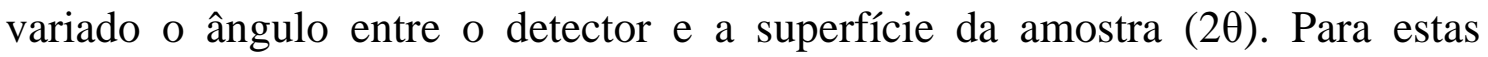
análises o ângulo Omega foi mantido constante e igual a $5^{\circ}$. 


\section{RESULTADOS E DISCUSSÕES}

\subsection{MICROSCOPIA ELETRÔNICA DE VARREDURA}

Na Figura 4.1, apresenta a micrografia obtida para as amostras do grupo controle (usinada $\mathrm{Ra}=2,5 \mu \mathrm{m}$ ) onde observam-se riscos de usinagem e imperfeições característicos do processo.

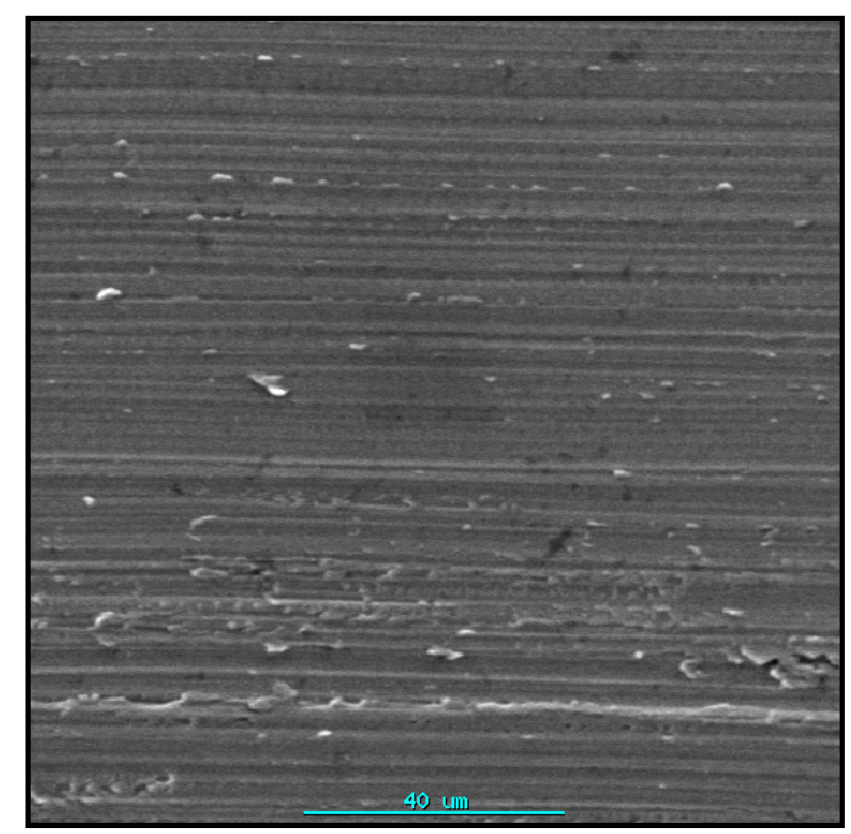

Figura 4.1 - Micrografia obtida para amostras após usinagem

Estudos prévios foram realizados para avaliar qual a molaridade ideal para a liga Ti-30Ta \%p (KIMAID et al., 2009). Os melhores resultados foram verificados para tratamentos com molaridade de $0,5 \mathrm{M}$, tempo de imersão de 24 horas e temperatura de $40^{\circ} \mathrm{C}$, condições adotadas no presente trabalho.

$\mathrm{Na}$ figura 4.2 é possível observar as amostras submetidas ao tratamento alcalino com $\mathrm{NaOH}, 60^{\circ} \mathrm{C}$ por 24 horas e tratamento térmico a $300^{\circ} \mathrm{C}$ por 1 hora. Observou-se a formação de um filme poroso similar ao verificado na literatura para Ti CP (JONASOVÁ et al., 2004) e para as ligas Ti-7,5Mo\%p (ESCADA, 2009) e Ti-6Al-4V (WANG, WANG e ZHOU, 2003). 


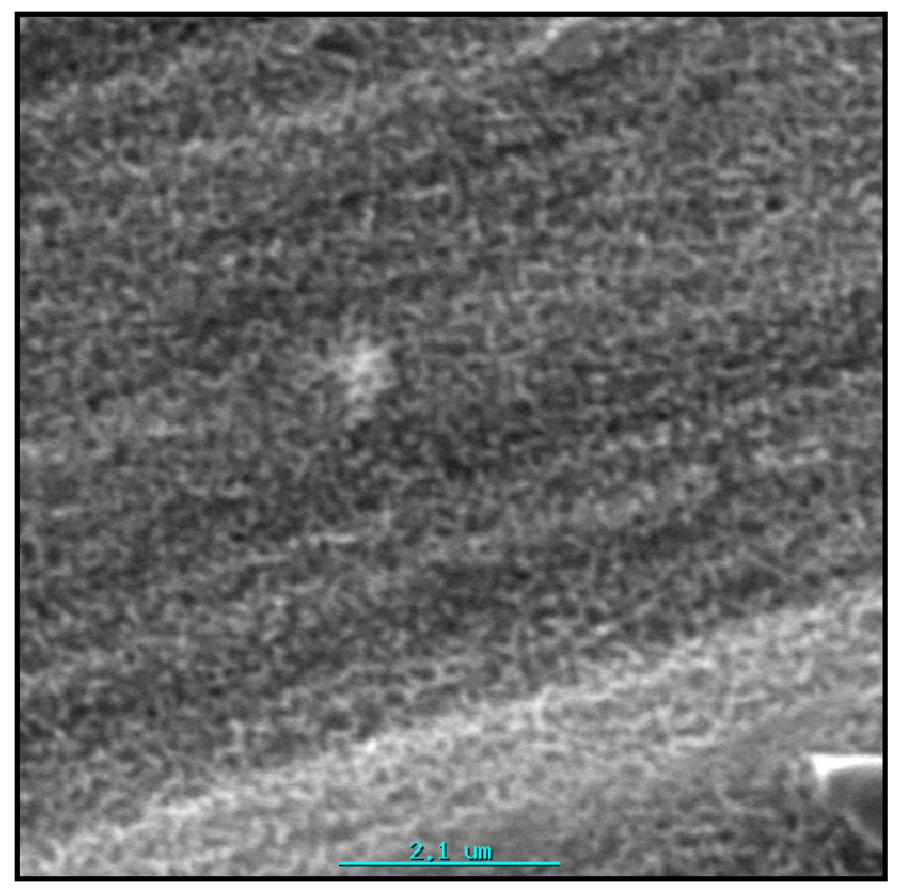

Figura 4.2 - Superfícies da amostra após tratamento alcalino e térmico

Partindo-se do princípio que as ligas de titânio apresentam comportamento similar ao TiCP, o tratamento alcalino levou à formação de uma camada de hidrogel de titanato de sódio, que após o tratamento térmico a $300{ }^{\circ} \mathrm{C}$ por 1 hora, resulta em titanato de sódio amorfo, tornando a superfície do metal termodinamicamente estável e com atividade iônica adequada para induzir a deposição do filme biocerâmico (VERCIK et al., 2003).

Após a imersão das amostras do grupo I e grupo II em SBF, a superfície destas apresentou diferença na maneira como a apatita foi depositada, de acordo com o tipo de solução SBF empregada ( $\mathrm{SBF}$ com Tris e $\mathrm{SBF}$ com $\mathrm{CO}_{2}$ ).

Nas amostras do grupo I, imersas por 7 e 14 dias, as superfícies ficaram recobertas por formações de agregados esferulíticos de apatita de diversos tamanhos, o que pode ser visualizado por meio do MEV (Figura 4.3 (a) e 4.3(b) respectivamente). 


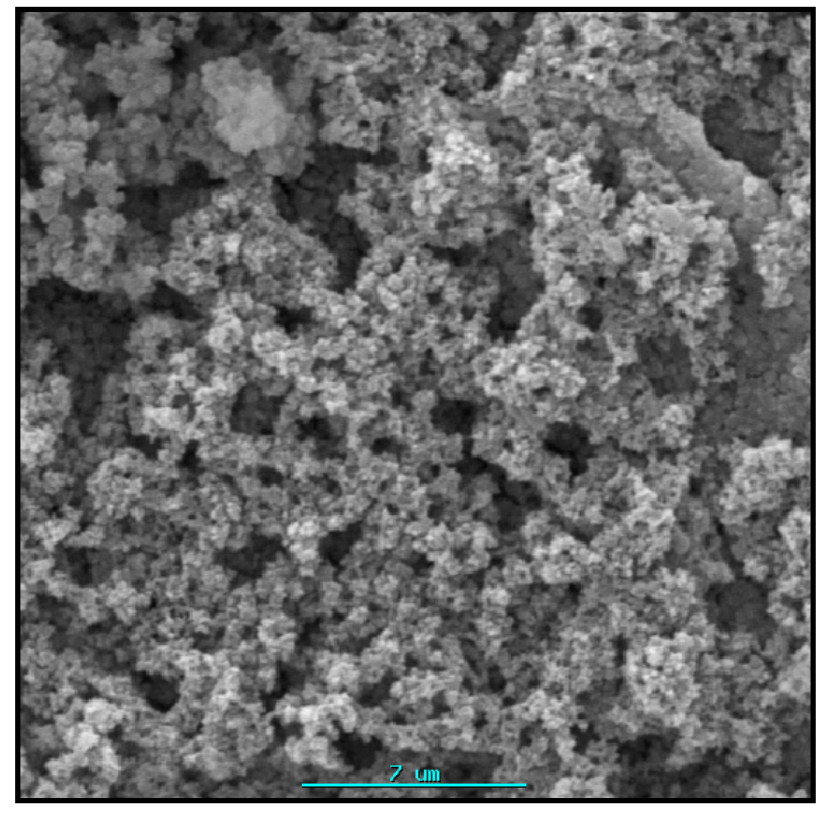

(a)

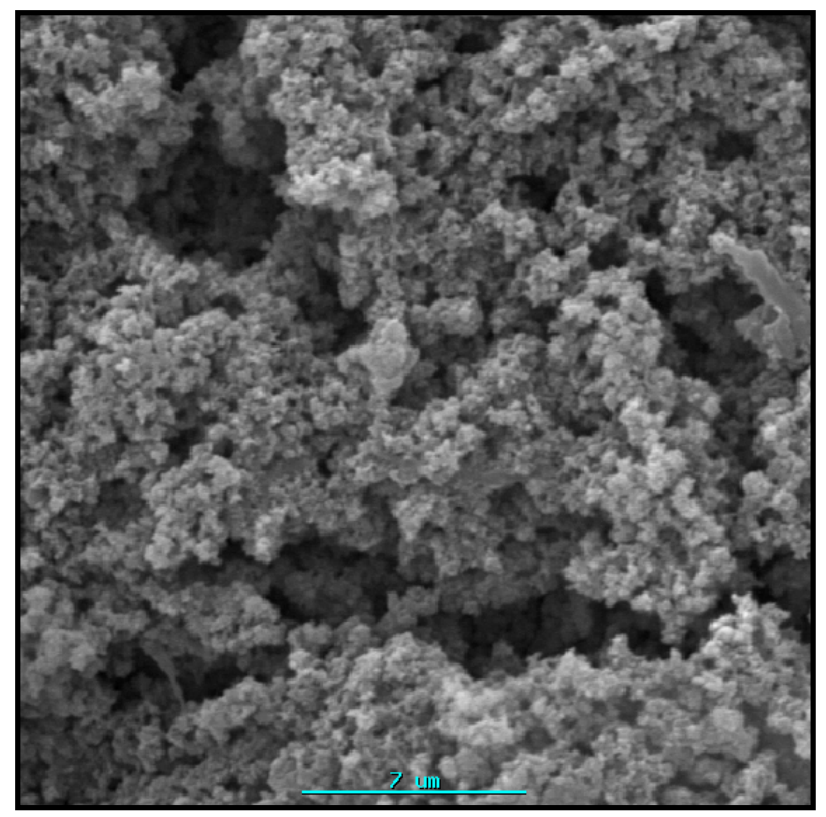

(b)

Figura 4.3 - Superfícies da amostra de Ti-30Ta após imersão em SBF com Tris por 7 dias (a) e por 14 dias (b)

Nas amostras do grupo II, após um dia de imersão no SBF, pode-se observar a formação de uma camada de fosfato de cálcio na superfície do 
substrato, cuja morfologia apresenta a formação de um nanofilme de apatita uniforme sobre a superfície da liga Ti-30Ta. (Figura 4.4).

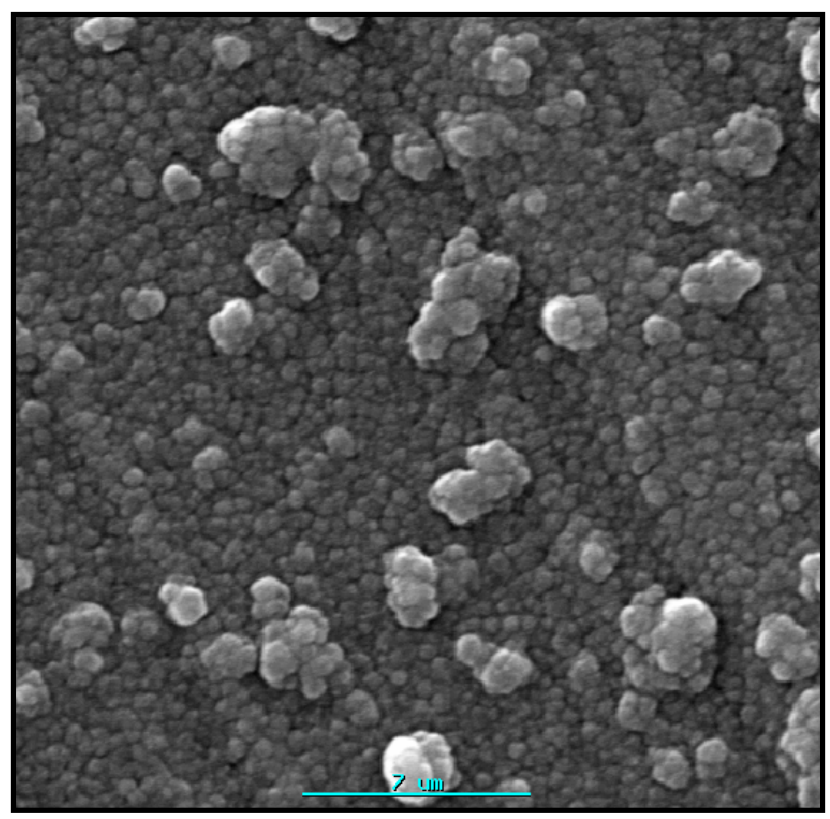

Figura 4.4 - Superfícies da amostra de Ti-30Ta após imersão em SBF com $\mathrm{CO}_{2}$ por 1 dia

A formação de uma camada de fosfato de cálcio em tempo inferior a $24 \mathrm{~h}$ foi possível devido ao uso de $\mathrm{CO}_{2}$ em SBF altamente concentrado. A cinética da deposição da camada é influenciada pela intensidade iônica da solução e a precipitação lenta de fosfato de cálcio na solução SBFx5 favorece a nucleação do fosfato de cálcio (HABBIBOVIC et al., 2002)

Esse resultado está de acordo com o estudo realizado por Barrère et al., (2002) em amostras Ti-6Al-4V, no qual dois parâmetros importantes foram destacados no processo de formação de fosfato de cálcio biomimético em soluções SBFx5. Primeiro, a precipitação na solução deve ser demorada para favorecer a nucleação heterogênea do fosfato de cálcio no substrato Ti-6Al-4V. Segundo, partículas de fosfato de cálcio depositadas no substrato devem ter tamanho nanométrico para permanecer fisicamente aderida no Ti-6Al-4V. 


\subsection{MICROSCOPIA DE FORÇA ATÔMICA - AFM}

Com a realização da microscopia de força atômica foi possível constatar os resultados observados anteriormente no microscópio eletrônico de varredura. Observou-se a partir das imagens uma topografia bastante irregular decorrente da formação dos agregados de apatita.

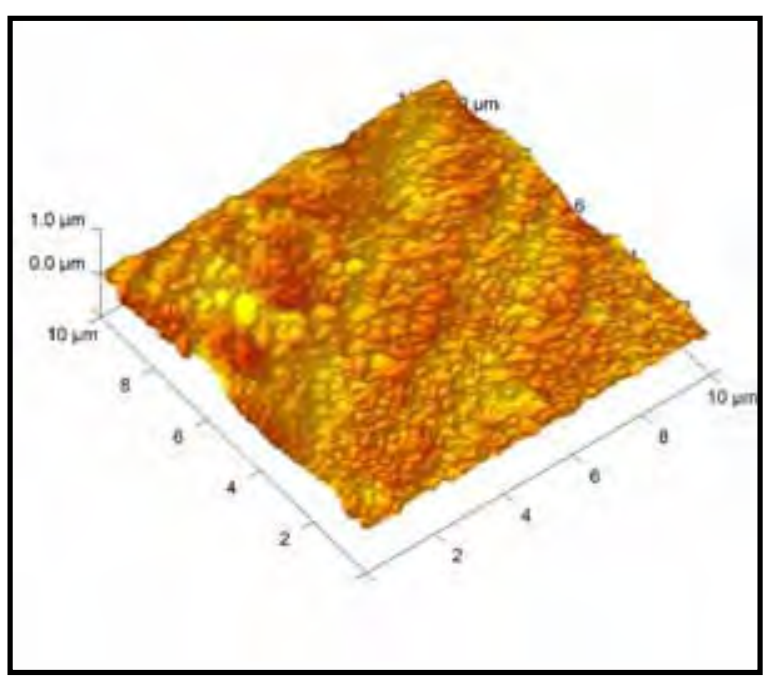

(a)

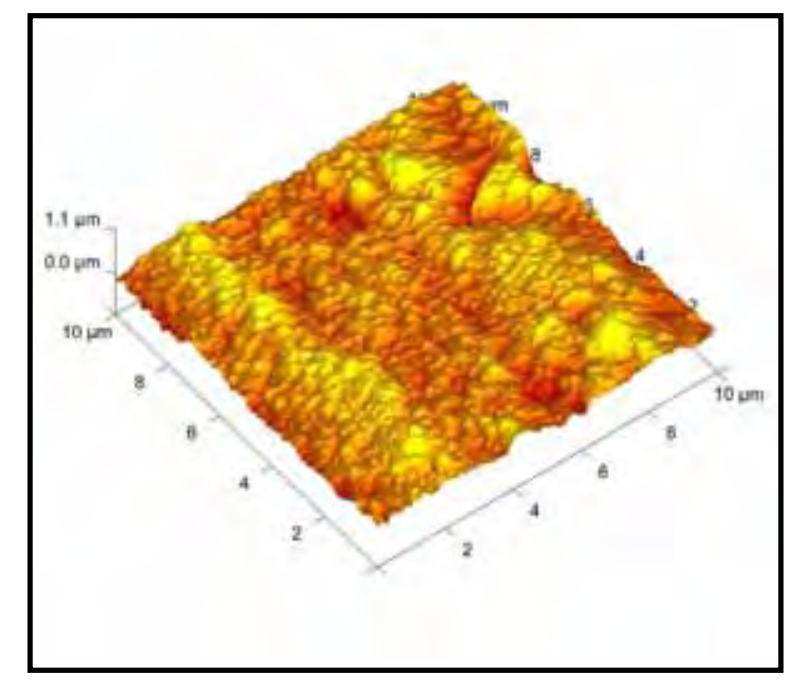

(b)

Figura 4.5 - Imagens obtidas a partir de microscopia de força atômica: (a) após imersão em SBF por 07 dias; (b)após imersão em SBF por 14 dias 
Para as amostras submetidas à solução acidificada com $\mathrm{CO}_{2}$ observou-se a formação de uma superfície com topografia uniforme conforme Figura 4.6.

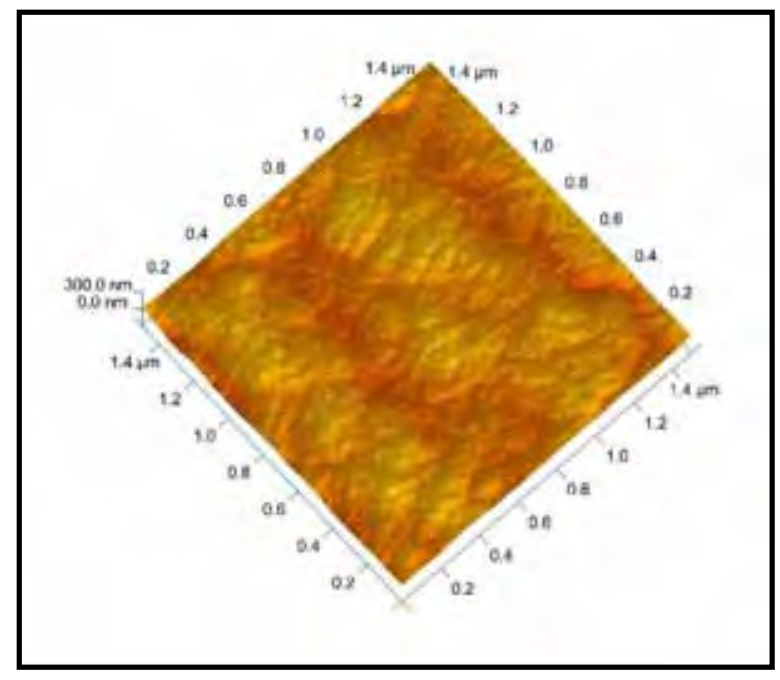

Figura 4.6 - Imagem obtida a partir de microscopia de força atômica após imersão em solução $\mathrm{SBF}$ por 1 dia $\left(\operatorname{com~} \mathrm{CO}_{2}\right)$

\section{3 ÂNGULO DE CONTATO}

Os resultados das medidas de ângulo de contato foram realizados apenas para o grupo II avaliados estão demonstrados no quadro 4.1.

Quadro 4.1- Medidas de ângulo de contato

\begin{tabular}{|c|c|}
\hline Amostras & Ângulo de Contato \\
\hline Ti-30Ta (controle usinado) & $82,5 \pm 0,98$ \\
\hline $\begin{array}{c}\text { Ti-30Ta+NaOH + HT } \\
\text { (filme) }\end{array}$ & $23,31 \pm 0,06$ \\
\hline NaOH + HT + SBF \\
(HA)
\end{tabular}

Como a relação entre o ângulo de contato e a molhabilidade ocorre de forma inversa em uma mesma superfície, uma diminuição deste ângulo eleva a capacidade de molhabilidade da superfície (LIM; DONAHUE, 2004). 
A figura 4.7 mostra a imagem da gota de água sobre a amostra controle (usinado) de Ti-30Ta e a imagem da gota de água sobre a amostra após recobrimento com apatita, apresentando coerência com os resultados obtidos para as medidas do ângulo de contato demonstrados na Tabela 4.1.

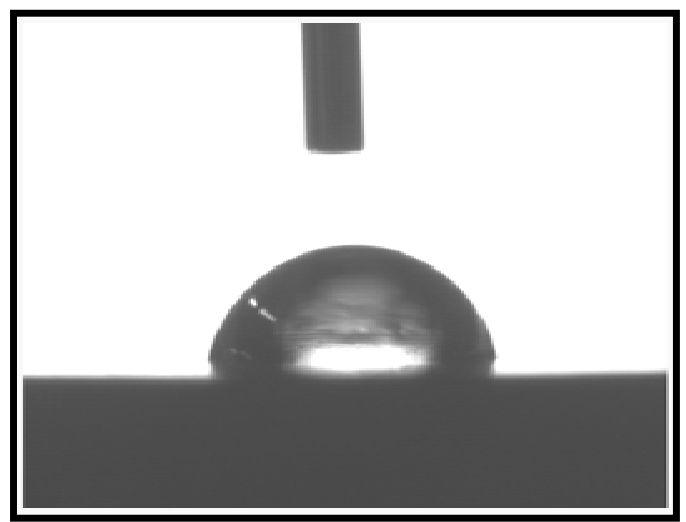

(a)

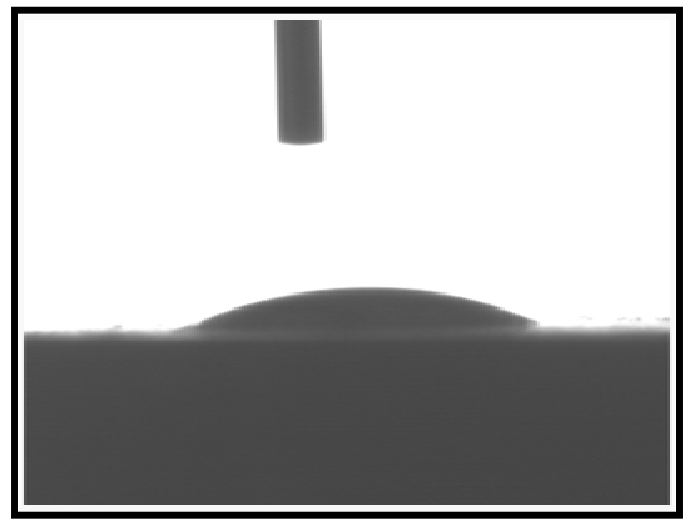

(b)

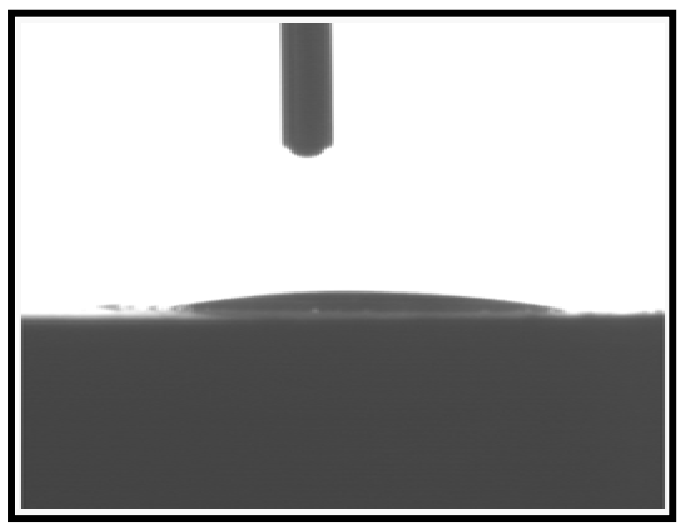

(c)

Figura 4.7 - Imagem da gota de água sobre a amostra de Ti-30Ta: (a) amostra controle usinado; (b) amostra após tratamento alcalino e térmico; (c) amostra após recobrimento com apatita. 
A partir dos resultados obtidos é possível concluir que a presença da apatita levou a uma maior hidrofilicidade do material com uma redução no valor do ângulo de contato de $82,5^{\circ}$ para $12,49^{\circ}$. Este resultado está de acordo com os estudos realizados por Chen et al. (2008) para o Ti CP.

\subsection{DIFRAÇÃO DE RAIOS X}

A figura 4.8 apresenta os difratogramas de Raios $X$, obtidos pela técnica de incidência rasante (ângulo de incidência de $5^{\circ}$ em relação à superfície da amostra), para as amostras de Ti-30Ta, Ti-30Ta tratada com $\mathrm{NaOH}\left(60^{\circ} \mathrm{C}\right.$ por 24 horas) e tratamento térmico $\left(300{ }^{\circ} \mathrm{C}\right.$ por 1 hora $)$, e Ti-30Ta imersas em SBF após os tratamentos alcalino e térmico.

Pode-se observar para a amostra de Ti-30Ta a presença de picos característicos das fases $\alpha\left(35,15^{\circ}, 39,95^{\circ}\right.$ e $\left.52,75^{\circ}\right)$ e $\beta\left(38,40^{\circ}\right)$. Para a amostra de Ti-30Ta tratada com $\mathrm{NaOH}\left(60^{\circ} \mathrm{C}\right.$ por 24 horas $)$ e tratamento térmico $\left(300{ }^{\circ} \mathrm{C}\right.$ por 1 hora ), foram observados estes mesmo picos, e não foram observados picos de novas fases formadas a partir da reação com $\mathrm{NaOH}$, conforme verificado na literatura por Kim et al. 1996 e Wang et al., 2003. Possivelmente a espessura do filme formado é muito fina de forma que pouco material do filme interagiu com o feixe de Raios $\mathrm{X}$, e como conseqüência a intensidade dos picos destas fases esta no mesmo nível da linha base.

Para a amostra de Ti-30Ta imersas em SBF após os tratamentos alcalino e térmico foram identificados picos característicos das fases $\alpha$ e $\beta$ titânio e hidroxiapatita (ficha JCPDF 86-0740, $\left.\mathrm{Ca}_{5}\left(\mathrm{PO}_{4}\right)_{3} \mathrm{OH}\right)$. A técnica de incidência de Raios X rasante deveria maximizar os picos das fases formadas na superfície (hidroxiapatita) e minimizar os picos das fases do substrato da liga de Ti-30Ta. Neste caso isto não ocorreu devido à pequena espessura do filme formado e 
porque a superfície da amostra não é plana (superfície de usinagem) e assim o feixe de Raios X interage apenas nas regiões elevadas (picos) do material.

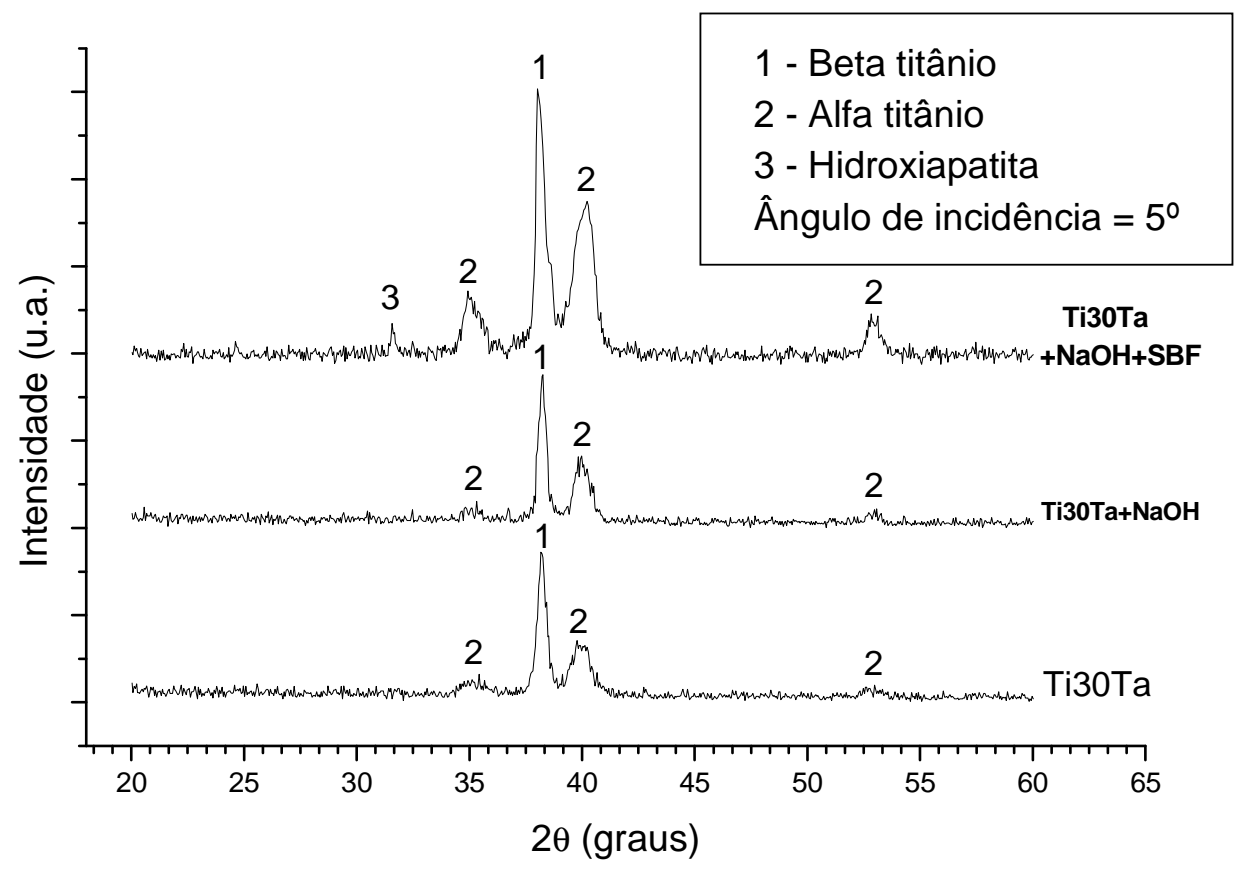

Figura 4.8 - Difratogramas de raios $\mathrm{X}$ 


\section{CONCLUSÃO}

A partir da realização do presente trabalho foi possível concluir que é possível obter uma liga Ti-30Ta, com recobrimento na sua superfície de apatita biológica.

Para as condições estudadas os melhores resultados foram obtidos para as amostras imersas em SBF com $\mathrm{CO}_{2}$. Essas amostras exibiram a formação de uma camada uniforme de apatita o que proporcionou maior molhabilidade.

As análises por microscopia de força atômica permitiram verificar que para as amostras submetidas a solução $\mathrm{SBF}$ com $\mathrm{CO}_{2}$ observou-se a formação de uma superfície com topografia uniforme Portanto este processo de recobrimento de apatitas mostrou-se extremamente eficiente para obtenção da hidroxiapatita semelhante à biológica, com baixa cristalinidade.

\subsection{SUGESTÃO PARA TRABALHOS FUTUROS}

A partir dos resultados obtidos serão confeccionados implantes da liga Ti-30Ta empregando-se os tratamentos desenvolvidos para observar "in vivo" a influência da modificação de superfície na osseointegração.

Também a partir das experiências vivenciadas, técnicas de caracterização complementares como espectroscopia de fotoelétrons excitados por Raios-X (XPS) e Espectroscopia Raman serão realizadas para avaliar os óxidos formados em cada etapa do tratamento. 


\section{REFERÊNCIAS BIBLIOGRÁFICAS}

ABE, Y., KOKUBO, T., YAMAMURO, T. Apatite Coating on Ceramics, Metals and Polymers utilizing a Biological Process. Journal of Materials Science: Materials in Medicine, Holanda, v. 1, n. 4, p. 233-238, nov. 1990.

ALMEIDA, E., ASSIS, C. M., VERCIK, L. O., GUASTALDI, A. C. Biomateriais: deposição de hidroxiapatita sobre superfície de ti-CP modificada por aspersão térmica. Química Nova, v.30, n. 5, p. 1229-1232, 2007

ALVES, A. P. R. Preparação de materiais compósitos in situ a partir de ligas eutéticas nos sistemas Nb-Al-Ti e Nb-Al-Cr. Faculdade de Engenharia Mecânica, Universidade Estadual de Campinas. Tese de doutorado, 1998.

ANKEM, S., GREENE, C.A. Recent developments in microstructure/property relationships of beta titanium alloys. Materials Science and Engineering A, v. 263, n. 2, p. 127-131, maio. 1999.

APARECIDA, A. H., LIA FOOK, M. V., SANTOS, M. L., GUASTALDI, A. C. Estudo da influência dos íons $\mathrm{k}+, \mathrm{Mg}^{2+}, \mathrm{SO}_{4}{ }^{2-}$ e $\mathrm{CO}_{3}{ }^{2-}$ na cristalização biomimética de fosfato de cálcio amorfo (ACP) e conversão a fosfato octacálcico (OCP). Quimica Nova, v. 30, n. 4, p. 892-896, maio. 2007

BALAZIC, M., KOPAC, J., JACKSON, M., AHMED, W. Review: titanium and titanium alloy applications in medicine. Int. J. Nano and Biomaterials , v.1, $\mathrm{n}^{\mathrm{o}} 1$, 2007

BARRERE, F., VAN BLITTERSWIJK, C.A., DE GROOT, K., LAYROLLE, P. Influence of ionic strength and carbonate on the Ca-P coating formation from SBFx 5 solution. Biomaterials, Bruxelas, v. 23, n. 9, p. 1921-1930, maio. 2002. 
BARRERE, F., SNEL, M.M., VAN BLITTERSWIJK, C. A., GROOT, K., LAYROLLE, P. Nano-scale study of the nucleation and growth of calcium phosphate coating on titanium implants. Biomaterials, Bruxelas, v.25, n.14, p. 2901-29140, junho. 2004.

CESCHIN, J.R. O implante na reabilitação bucal , São Paulo , v.3 , p. 84-123 , 1984

DONACHIE M. Titanium: A Technical Guide, ASM International, Metals Park, OH, 1989.

DUAN, K., WANG, R. Surface modifications of bone implants through wet chemistry. Journal of Materials Chemistry, v. 16, n. 24, p. 2309-2321, 2006.

GEETHA, M., MUDALI, U. K., ASOKAMANI, R., RAJ. B. Corrosion and microstructural aspects of titanium and its alloys as orthopadeic devices. Corrosion Reviews Special Issue, v. 21, n. 2-3, p. 125 - 159, 2003.

GEETHA, M., SINGH, A.K., ASOKAMANI, R., GOGIA, A.K. Ti based biomaterials, the ultimate choice for orthopaedic implants - A review. Progress in Materials Science, v. 54, n. 3, p. 397 - 425, maio. 2009.

GIANNOUDIS, P. V., DINOPOULOS, H., TSIRIDIS, E. Bone substitutes: An update. Injury - Proceedings from the 1st European Clinical Symposium on Bone and Tissue Regeneration, v.36, n. 3, p. 20-27, nov. 2005

GIBBESCH, B., ELSSNER, G., MADER, W., FISCHMEISTER, H.. Ceramic Engineering and Science Proceedings, v. 10, n. 11-12, p. 1503 - 1510 , 1989

GODLEY, R., STAROSVETSKY, D., GOTMAN, I. Bonelike apatite formation on niobium metal treated in aqueous $\mathrm{NaOH}$. Journal of Materials Science: Materials in Medicine, Holanda, v.15, n.10, p.1073-1077, out. 2004. 
HABIBOVIC, P., BARRÉRE, F., VAN BLITTERSWIJK, C.A., GROOT, K., LAYROLLE, P. Biomimetic Hydroxyapatite Coating on Metal Implants. Journal of the American Ceramic Society, Holanda, v.85, n.3, p.517-522, mar.2002.

HENCH, L. L. Biomaterials: a forecast for the future. Biomaterials, n.19, p. 14194231, 1998.

JALOTA, S., BHADURI, S.B., TAS, A.C. Effect of carbonate content and buffer type on calcium phosphate formation in SBF solutions, Journal of Materials Science: Materials Medicine, Holanda, v.17, n.7, p.697-707, jul.2006.

JONASOVA, L., MUller, F.A., HELEBRANT, A., STRNAD, J., GREIL, P. Biomimetic apatite formation on chemically treated titanium, Biomaterials v.25, n.78, p.1187-1194, mar-abr.2004.

JONES, F.H. Teeth and bones : applications of surface science to dental materials and related biomaterials . Surface Science Reports v. 42, p.75-205 , 2001

KAWACHI, E.Y., BETRAN, C. A., REIS, R. R., ALVES, O. L.. Biocerâmicas: Tendências e Perspectivas de uma Área Interdisciplinar. Química Nova, v. 23, n. : p. 518-522, 2000.

KIM, H.M., MIYAJI, F., KOKUBO, T., NAKAMURA, T., Preparation of bioactive Ti and its alloys via simple chemical surfaces. Journal of Biomedical Materials Research, Cleveland, v. 32, n,3, p.409-417, nov.1996.

KIM, S., RYU, H. S., SHIN, H., JUNG, K. S., HONG, K. S. In situ observation of hydroxyapatite nanocrystal formation from amorphous calcium phosphate in calciumrich solutions. Materials Chemistry and Physics, v. 91, n. 1-2, p. 500-506, junho. 2005. 
KOKUBO, T. Apatite formation on surfaces of ceramics, metals and polymers in body environment. Acta Biomaterialia, Oxford, v.46, n.7, p.2519-2527, abr. 1998.

KOKUBO, T., TAKADAMAN, H. How useful is SBF in predicting in vivo bone bioactivity? Biomaterials, Bruxelas, v.27, n.15, p.2907-2915, jan.2006.

LI, F., FENG, Q.L., CUI, F.Z. A simple biomimetic method for calcium phosphate coating. Surface \& Coatings Technology, v. 154, n. 1, p. 88-93, 2002.

LIM, J.Y., DONAHUE, H.J. Biomaterials characteristics important to skeletal tissue engineering. Journal of Musculoskeletal and Neuronal Interactions, Pensilvânia, v.4, n.4, p.396-398, dez. 2004.

LIN, F. H., HSU, Y. S., LIN, S. H., SUN. J. S. The effect of Ca/P concentration and temperature of simulated body fluid on the growth of hydroxyapatite coating on alkalitreated 316L stainless steel. Biomaterials, Bruxelas, v. 23, n. 19, p. 4029-4038, out. 2002

LIU, X., CHU, P.K., CHUANXIAN, D. Surface modification of titanium, titanium alloys, and related materials for biomedical applications. Materials Science and Engineering R, Nova York, v.47, n.3-4, p. 49-121, dez. 2004.

LONG, M., RACK, H. J. Titanium alloys in total joint replacement-a materials science perspective. Biomaterials, Bruxelas, v.19, n. 18, p. 1621-1639, set.1998.

LU, X., LENG, Y. TEM study of calcium phosphate precipitation on bioactive titanium surfaces. Biomaterials, Bruxelas, v. 25, n. 10, p. 1779 - 1786, maio. 2004.

LU, X., LENG, Y. Theoretical analysis of calcium phosphate precipitation in simulated body fluid. Biomaterials, Bruxelas, v. 26, n.10, p.1097-1108, jun. 2005. 
MURRAY, G.T. Handbooks of Materials Selection for Engineering Applications (1997).

MURRAY, J.L Phase Diagrams of binary titanium alloys; ASM, International, Metals Park, Ohice, 1997.

MIYAZAKI, M., IWASAKI, K., ONOSE, H., MOORE, B.K. Resin modifed glassionomers effect of dentin primer application on the development of bond strength. European journal of Oral Science, v.107, n.5, p.393-399, out. 1999.

MIYAZAKI, T., KIM, H. M., MIYAJI, F., KOKUBO, T., KATO, H., NAKAMURA, T. Bioactive tantalum metal prepared by $\mathrm{NaOH}$ treatment. Journal of Biomedical Materials Research Part A, v. 50, n. 1, p. 35-45, jan. 2000.

MIYAZAKI, T., KIM, H. M., KOKUBO, T. Induction and acceleration of bonelike apatite formation on tantalum oxide gel in simulated body fluid. Journal of Sol-Gel Science and Technology, v. 21, n.1-2 , p. 83 - 88, jun. 2001.

NIINOMI, M. Mechanical properties of biomedical titanium alloys. Materials Science and Engineering A, v. 243, n.1-2 , p. 231 - 236, março. 1998

OH, S.H., FINÕNES, R.R., DARAIO, C., CHEN, L.H., JIN, S. Growth of nano-scale hydroxyapatite using chemically treated titanium oxide nanotubes. Biomaterials, Bruxelas, v.26, n.24, p. 4938-4943, ago.2005.

PRIGENT, H., MUSSI, P. P., CATHELINEAU, G., MALlET, M. B. Evaluation of the biocompatibility of titanium-tantalum alloy versus titanium. Journal of biomedical materials research, v. 39, n. 2, p. 200 - 206, 1998.

PURCEK, G., SARAY, O., KUL, O., KARAMAN, I., YAPICI, G.G., HAOUAOUI, M., MAIER, H.J. Mechanical and wear properties of ultrafine-grained pure Ti 
produced by multi-pass equal-channel angular extrusion. Materials Science and Engineering A, v. 517, n. 1-2, p. 97-104, ago. 2009.

ROHANIZADEH, R., AL-SADEQ M., LEGEROS, R. Z. Preparation of different forms of titanium oxide on titanium surface: Effects on apatite deposition. Journal of Biomedical Materials Research Part B: Applied Biomaterials, v. 71, n. 2, p. 343 352, set. 2004.

SHENK, R.K., BUSER, D. Osseointegration: a reality. Periodontology 2000, v.17, n.1, p.22-25, 1998

SHIBLI, S. M. A., MATHAI, S. The role of calcium gluconate in electrochemical activation of titanium for biomimetic coating of calcium phosphate. Journal of Biomedical Materials Research Part A, v. 87A, n. 4, p 994-1002, 2008.

SOMRANI, S., BANU, M., JEMAL, M., REY, C. Physico-chemical and thermochemical studies of the hydrolytic conversion of amorphous tricalcium phosphate into apatite. Journal of Solid State Chemistry, v. 178, n. 5, p. 1337 1348, maio 2005.

UCHIDA, M., KIM, H.M., KOKUBO, T., FUJIBAYASHI, S., NAKAMURA, T. Structural dependence of apatite formation on titania gels in a simulated body fluid. Journal of Biomedical Materials Reserch Part A, Cleveland , v.64, n.1 p.164 -170, jan.2003.

VALLET-REGí, M. Ceramics for medical applications Journal of Chemical Soc. Dalton Trans, v. 2, p. 97 - 108, 2001.

VALLET-REGI, M., GONZALEZ-CALBET, J.M. Calcium phosphates as substitution of bone tissues. Progress in Solid State Chemistry, v. 32, n. 1-2, p.1-31, 2004. 
VALLET-REGÍ, M., BALAS, F., COLILlA, M., MANZANO, M. Drug Confinement and Delivery in Ceramic Implants. Drug Metabolism Letters, v. 1, n. 1, p. 37-40, 2007.

VERCIK, L. C. O., ASSIS, C. M., LIA FOOK, M. V., SANTOS, M. L., GUASTALDI, A. C. Recobrimento de apatitas "in vitro" sobre titânio - influência do tratamento térmico. Eclética Química, São Paulo, v. 28, n. 1, p.25-31, 2003.

XUE, W., LIU, X., ZHENG, X., DING, C. In vivo evaluation of plasma-sprayed titanium coating after alkali modification Biomaterials, Bruxelas, v. 26, n.16, p.30293037, jun. 2005.

YAN, W.Q., NAKAMURA, T., KOBAYASHI, M., KIM, H.M., MIYAJI, F., KOKUBO, T. Bonding of chemically treated titanium implant to bone. Journal of Biomedical Material Research Part A, Cleveland, v.37, n.2, p.267-275, nov. 1997.

YAN, W.Q., NAKAMURA, T., KAWANABE, K. Apatite layer-coated titanium for use as bone bonding implants. Biomaterials, Bruxelas, v. 18, n. 17, p. 1185- 1190, set. 1997.

WANG, K. The use of titanium for medical applications in the USA. Materials Science and Engineering A, v.213, n.1-2, p. 134-137, agosto. 1996.

WANG, X. J., LI, Y. C., LIN, J. G., YAMADA, Y., HODGSON, P. D., WEN, C. E. In vitro bioactivity evaluation of titanium and niobium metals with different surface morphologies. Acta Biomaterialia, v. 4, n.5 p. 1530-1535, set. 2008.

WEI, M., UCHIDA, M., KIM, K.M., KOKUBO, T., NAKAMURA, T. Apatite forming ability of calcium-containing titania. Biomaterials, Bruxelas, v.23, n.1, p.167 - 172, jan. 2002 
ZHOU, Y.L., NIINOMI, M., AKAHORI, T. Effects of Ta content on Young's modulus and tensile properties of binary Ti-Ta alloys for biomedical applications. Materials Science and Engineering A, v.371, n.1-2, p. 283-290, abril. 2004.

ZHOU, Y.L., NIINOMI, M. Ti-25Ta alloy with the best mechanical compatibility in Ti-Ta alloys for biomedical applications. Materials Science and Engineering C, v.29, n. 3, p.1061-1065, abril. 2009. 